\title{
DAMPAK SERTIFIKASI GURU TERHADAP PERILAKU SOSIAL DAN EKONOMI GURU DI KABUPATEN NGAWI
}

\author{
Maretha Riana Ramdhani, \\ marethariana@gmail.com \\ Vincent Hadiwiyono, \\ Lukman Hakim \\ Universitas Sebelas Maret Surakarta \\ Fakultas Ekonomi dan Bisnis \\ Program Studi Magister Ekonomi dan Pembangunan
}

\begin{abstract}
This study aims to explain the impact of teacher certification on teachers' social and economic behavior in Ngawi District by identifying, explaining some of social and economic impacts both positive or negative influence, andthen analyzing the impacts. This type of research is descriptive qualitative. The sampling technique was done by snowball sampling. The data collection methods used are in-depth interview, direct observation and document recording. Data validity use source triangulation. Data analysis techniques use data reduction, data display and verification. The results showed that incentive received from teacher certification in some schools causes change in social behavior between the receiver and non-receiver of teacher certification. Teacher certification also affect economic behavior in teacher profession both in state and private schools as seen in the improved teachers' welfare.
\end{abstract}

Key words: teacher certification, incentive, profession, social, economy

\begin{abstract}
ABSTRAK
Penelitian ini dilakukan di Kabupaten Ngawi, dengan tujuan untuk mengidentifikasi, dan menjelaskan beberapa dampak sertifikasi guru terhadap perilaku sosial dan ekonomi guru di Kabupaten Ngawi, baik dampak positif maupun dampak negative. Jenis penelitian ini bersifat deskriptif kualitatif. Teknik pengambilan sampel dilakukan dengan snowball sampling. Metode pengumpulan data yang digunakan adalah wawancara mendalam, pengamatan langsung dan mencatat dokumen. Validitas data menggunakan triangulasi sumber. Teknik analisis data menggunakan reduksi data, display data dan verifikasi. Hasil penelitian menunjukkan bahwa pemberian tunjangan atau insentif yang didapat dari sertifikasi guru di beberapa sekolah menimbulkan perubahan perilaku sosial antara guru yang mendapat insentif dengan guru yang tidak mendapat insentif. Sertifikasi guru juga berpengaruh terhadap perilaku ekonomi pada profesi guru baik di sekolah Negeri maupun Swasta, yang tampak dengan meningkatnya kesejahteraan hidup mereka.
\end{abstract}

Kata kunci: sertifikasi guru, insentif, profesi, sosial, ekonomi

\section{PENDAHULUAN}

Pemerintah sangat berkomitmen menyelenggarakan pendidikan untuk mencerdaskan generasi penerus dengan menyediakan dana yang didistribusikan dalam rangka peningkatan kualitas pendidikan. Majunya sebuah negara didasarkan pada lulusan yang memiliki kompetensi dan memenuhi tuntutan masyarakat secara umum. Muzammil (2016:183) menyatakan bahwa corak pendidikan beserta arah dan tujuan pendidikan sangat dipengaruhi oleh situasi politik yang ditetapkan oleh pemerintah. Oleh karena itu, keikutsertaan pemerintah dalam menangani pola pendidikan sangat besar peranannya dengan didukung oleh berbagai kebijakan yang ditetapkan untuk meningkatkan keber- 
hasilan pendidikan bagi seluruh warga negara Indonesia.

Pendidikan guru menjadi masalah penting dalam masa perluasan pendidikan. Sekolah guru (Kweekschool) pertama dibuka pada tahun 1852 di Solo, dan segera diikuti oleh sekolah guru lainnya di pusat bahasabahasa utama di Indonesia. Sekolah-sekolah ini menghasilkan lebih dari 200 guru antara tahun 1887 dan 1892, namun jumlah tersebut menurun setelah adanya depresi ekonomi (Nasution, 2008:40).

Pendidikan merupakan salah satu aspek yang sangat penting terhadap kemajuan suatu bangsa. Semakin bagus kualitas pendidikan akan semakin menentukan arah perbaikan kualitas sumber daya manusia. Tinggi rendahnya tingkat pendidikan masyarakat dapat mempengaruhi dinamika perubahan ataupun kualitas kehidupan sosial ekonomi penduduk suatu daerah. Pendidikan merupakan sarana dalam menyiapkan sumberdaya manusia untuk pembangunan suatu bangsa. Pendidikan berperan penting dalam pengentasan kemiskinan dan memberikan ketrampilan kepada seluruh masyarakat untuk mencapai potensinya secara optimal. Adanya sertifikasi guru sebagai kelengkapan komponen pendidikan yang memadai diharapkan dapat mengubah pola pikir masyarakat ke arah yanglebih maju. Pembangunan pendidikan merupakan kegiatan investasi pada sumber daya manusia. Semakin banyak terciptaSDM yang berkualitas di suatu daerah, maka kedepannya akan menguntungkan daerah tersebut. Masalah pendidikan bagi Provinsi Jawa Timur menjadi skala prioritas pembangunan terutama di Kabupaten Ngawi.

Profesi guru memiliki peran yang strategis dalam bidang pendidikan, bahkan sumber daya pendukung lain yang memadai seringkali kurang berarti apabila tidak disertai dengan kualitas guru yang baik. Begitu juga yang terjadi sebaliknya, apabila guru berkualitas tidak ditunjang oleh sumber daya pendukung lain yang memadai juga dapat menyebabkan kurang optimal kinerjanya, sehingga guru yang baik dan profesional merupakan ujung tombak dalam upaya peningkatan kualitas hidup masyarakat dan pembangunan wilayah di sekitarnya. Dalam berbagai kasus, kualitas layanan sistem pendidikan secara keseluruhan berkaitan dengan kualitas guru. Untuk itu, peningkatan kualitas pendidikan harus dilakukan melalui upaya peningkatan kualitas dan profesional kerja guru.

Terkait aspek kedisiplinan guru dalam pembelajaran telah dilakukan penelitian oleh Suprastowo (2013). Penelitian dilakukan pada subyek guru di 168 SD di 20 Kabupaten yang ada di Indonesia dan faktor yang diuji adalah ketidakhadiran guru dalam proses pembelajaran. Hasil penelitian tersebut menunjukkan bahwa data mengenai tingkat ketidakhadiran guru SD dalam pembelajaran sebesar $6,6 \%$ dan mayoritas guru yang tidak hadir berstatus Pegawai Negeri Sipil (PNS) serta memiliki sertifikat sebagai pendidik. Ketidakhadiran guru dalam proses pembelajaran tersebut dipengaruhi beberapa faktor diantaranya tugas dinas dan beberapa kegiatan yang memiliki ijin secara resmi.

Chicarell (Teacher of Exellence dari Alaska) menyatakan bahwa"Saya memiliki keyakinan mendasar bahwa para orang tua telah menunjukkan kepercayaan mereka terhadap diri saya dan sekolah ketika mereka mengirimkan anak-anaknya ke sekolah. Saya hanya menekankan cinta, kepedulian, dan perhatian yang dimiliki dan telah dibangun oleh orang tua anakanak saat sekolah dan saya bekerja sama dengan keluarga selama tahun ajaran".

Pembahasan ini memang "seolah" ingin membedakan siapakah seorang guru tersebut, meski sebenarnya yang dimaksud disini adalah bahwa seorang guru hendaknya dituntut untuk menjadi pribadi-pribadi yang unggul.

Pengakuan masyarakat terhadap profesionalitas guru sekarang ini dianggap sebagai isu yang sangat penting. Isu tersebut timbul disamping disebabkan adanya tuntutan para guru terhadap tingkat kesejahteraan mereka, juga disebabkan oleh realita mutu pendidikan yang masih rendah 
yang salah satu faktor penyebabnya adalah rendahnya kualitas guru atau sedikitnya jumlah guru yang profesional. Oleh karena itu Pemerintah R.I. berdasarkan Permendiknas Nomor 18 Tahun 2007 berusaha memberi sertifikasi terhadap para guru yang telah dianggap profesional melalui Uji Sertifikasi dalam bentuk penilaian portofolio yang merupakan pengakuan atas pengalaman profesional guru dalam bentuk penilaian terhadap kumpulan dokumen yang mencerminkan kompetensi guru.

Sertifikasi guru merupakan salah satu cara dalam dunia pendidikan untuk meningkatkan kualitas dan profesionalitas seorang guru, sehingga ke depan semua guru harus memiliki sertifikat sebagai lisensi atau ijin mengajar. Dengan demikian, upaya pembentukan guru yang profesional di Indonesia segera menjadi kenyataan seperti yang diharapkan.

Sobhron (2016) melakukan penelitian tentang pengaruh kinerja guru dalam meningkatkan manajemen mutu pendidikan dengan lokasi penelitian di Madrasah Ibtidaiyah Muhammadiyah Sudun Kedungtuban Blora. Hasil uji diperoleh data bahwa manajemen mutu pendidikan terdiri atas 3 komponen penting yaitu: (1) Kinerja akademik guru yang telah memiliki sertifikasi telah dicapai secara efektif dan efisien mulai aspek perencanaan (planning) dan pelaksanaan $(d o)$ pengembangan mutu pendidikan, (2) Pengembangan mutu pembelajaran telah dicapai oleh guru tersertifikasi sesuai dengan visi dan misi sekolah yang ditetapkan (3) Kinerja guru tersertifikasi sangat mendukung ke arah pencapaian manajemen pengelolaan lembaga Pendidikan yang baik.

Pada tahun 2013 serifikasi guru mempunyai dampak ekonomi terutama terhadap peningkatan Indeks Pembangunan Manusia (IPM) di Jawa Timur khususnya di Kabupaten Ngawi dan Kabupaten lainnya seperti Kediri, Magetan, Bangkalan, Sumenep, Lumajang, Sidoarjo, Madiun, Blitar, Trenggalek, Pacitan, Jombang, Malang, Nganjuk, Kota Pasuruan, Kota Mojokerto, dan Kota Kediri terletak di kuadran III dengan rata-rata pertumbuhan ekonomi dan peningkatan IPM di bawah rata-rata provinsi (low growth, less pro-human development). Kondisi ini menegaskan perlunya pemerintah daerah membenahi pelayanan publik di bidang pendidikan dan kesehatan.

Semakin meningkat kualitas dan profesionalitas seorang guru, semakin baik pula kualitas negara tersebut. Itulah asumsi secara umum terhadap program pendidikan suatu negara. Pendidikan merupakan suatu upaya mencerdaskan kehidupan bangsa dan meningkatkan harkat dan martabat manusia melalui pendidikan, diharapkan dengan meningkatnya kehidupan suatu bangsa maka peningkatan kehidupan manusia kearah yang lebih sempurna dapat tercapai.

Upaya-upaya yang dapat dilakukan untuk meningkatkan kualitas pendidikan di Indonesia antara lain, melalui program sertifikasi guru. Sertifikasi guru adalah sebuah penunjang dalam peningkatkan sumber daya manusia terutama para profesi guru disekolah-sekolah.

Salah satu dampak yang ditimbulkan oleh sertifikasi guru adalah perilaku sosial dan ekonomi para gurusebagai penerima tunjangan profesi guru. Status sosial ekonomi adalah gambaran tentang keadaan seseorang atau suatu masyarakat yang ditinjau dari segi sosial dan ekonomi, seperti tingkat pendidikan, pendapatan, pekerjaan, dan pemilikan barang. Setiap individu atau masyarakat pasti menginginkan status sosial ekonomi yang lebih baik, namun pada kenyataannya masih banyak individu atau masyarakat yang berstatus sosial ekonomi rendah.

Bome dan Walles (dalam Myers, 1983:20) menyatakan bahwa individu yang mempunyai tingkat ekonomi menengah keatas akan cenderung lebih memiliki pola konsumsi yang berlebihan dari pada mereka yang memiliki tingkat ekonomi menengah kebawah. Individu atau masyarakat lebih menghargai kekayaan material dibandingkan dengan yang lainnya, individu yang mempunyai kekayaan akan menempati 
posisi atau lapisan paling atas, sedangkan mereka yang tidak memiliki kekayaan, akan selamanya berada dilapisan masyarakat yang paling bawah.

Status sosial ekonomi sangat berpengaruh bagi pemenuhan kebutuhan hidup sehari-hari. Manusia sebagai makhluk sosial mempunyai potensi serta kepribadian yang memungkinkan dia diterima dalam pergaulan dengan individu yang lain. Karena setiap individu akan menyalurkan potensinya tersebut untuk kepentingan tertentu, kemudian individu yang lain dapat menerima dan mengakuinya. Atas dasar itulah dia akan mendapat status itu di dalam kelompok dimana dia berada. Selain itu, besarnya pengaruh sertifikasi guru dan motivasi kerja guru terhadap kinerja guru dapat dijadikan masukan bagi guru agar lebih memperbaiki kinerjanya pasca sertifikasi (Melati et al., 2013)

Berdasarkan uraian yang diungkapkan di atas, maka penelitian tentang "Dampak Sertifikasi Guru Terhadap Perilaku Sosial dan Ekonomi Guru di Kabupaten Ngawi" perlu di lakukan.

Permasalahan utama penelitian ini dapat dirumuskan sebagai berikut: (1) Bagaimana dampak sertifikasi guru terhadap perilaku sosial penerima tunjangan profesi gurudi Kabupaten Ngawi?; (2) Bagaimana dampak sertifikasi guru terhadap prilaku ekonomi penerima tunjangan profesi guru di Kabupaten Ngawi?

Tujuan yang diharapkan dari penelitian ini adalah sebagai berikut: (1) Untuk mengetahui dampak sertifikasi guru terhadap perilaku sosial penerima tunjangan profesi guru di Kabupaten Ngawi; (2) Untuk mengetahui dampak sertifikasi guru terhadap perilaku ekonomi penerima tunjangan profesi guru di Kabupaten Ngawi.

\section{TINJAUAN TEORETIS \\ Pengertian Profesi}

Secara harfiah kata profesi berasal dari kata profession yang berasal dari bahasa latin profesus yang berati "mampu atau ahli dalam suatu bentuk pekerjaan". Dalam Webster's
New World Dictionary ditemukan bahwa profesi merupakan suatu pekerjaan yang menuntut pendidikan tinggi dalam liberal art's atau since dan biasanya meliputi pekerjaan mental yang ditunjang oleh kepribadian dan sikap profesional (Alma, 2012:115-116).

\section{Pengertian Sertifikasi}

Sertifikasi adalah proses pemberian sertifikat kepada guru yang telah memenuhi persyaratan tertentu, yaitu memiliki kualifikasi akademik, kompetensi, sehat jasmani dan rohani, serta memiliki kemampuan untuk mewujudkan tujuan pendidikan nasional, yang dibarengi dengan peningkatan kesejahteraan yang layak (Muslich, 2007:12). Sertifikasi bagi guru dalam jabatan sebagai salah satu upaya peningkatan mutu guru diharapkan dapat meningkatkan mutu pendidikan pada satuan pendidikan formal secara berkelanjutan. Untuk meningkatkan mutu guru hal yang tidak bisa dilupakan adalah kualifikasi akademik, kompetensi, dan sertifikasi pendidik. Sertifikat pendidik merupakan bukti formal pengakuan yang diberikan kepada guru sebagai tenaga professional (Fuad, 2017).

Sertifikasi guru adalah proses uji kompetensi yang dirancang untuk mengungkapkan penguasaan kompetensi seseorang sebagai landasan pemberian sertifikat pendidik (Mulyasa, 2009:34). Sertifikasi guru merupakan salah satu amanat yang tertulis dalam Undang-Undang No 20 Tahun 2003 tentang Sisdiknas bagian kedua tentang sertifikasi, pasal 61 menyatakan: (1) Sertifikat berbentuk ijazah dan sertifikat kompetensi.; (2) Ijazah diberikan kepada peserta didik sebagai pengakuan terhadap prestasi belajar dan/atau penyelesaian suatu jenjang pendidikan setelah lulus ujian yang diselenggarakan oleh satuan pendidikan yang terakreditasi; (3) Sertifikasi kompetensi diberikan oleh penyelenggara pendidikan dan lembaga pelatihan kepada peserta didik dan warga masyarakat sebagai pengakuan terhadap kompetensi untuk melakukan pekerjaan tertentu setelah lulus uji kompetensi 
yang diselenggarakan oleh satuan pendidikan yang terakreditasi atau lembaga sertifikasi; (4) Ketentuan mengenai aspek akreditasi sebagaimana dimaksud dalam ayat (1), ayat (2), dan ayat (3) diatur lebih lanjut dengan Peraturan Pemerintah.

Berdasarkan definisi, tujuan, dan manfaat sertifikasi guru dapat disimpulkan bahwa sertifikasi guru pada akhirnya berorientasi pada pencapaian dan peningkatan mutu pendidikan. Secara teoritik hal ini dikemukakan oleh Hermawan (2007:33) yaitu "Secara teoritis, proses sertifikasi yang dilakukan dengan benar akan berkontribusi positif terhadap mutu pendidikan. Mutu pendidikan adalah keadaan kurang baiknya kondisi, layanan, dan hasil pendidikan di suatu sekolah berdasarkan kriteria ideal dan harapan masyarakat".

Rasyid (2014:436) menyatakan bahwa guru yang memiliki tugas pokok untuk melakukan tugas bidang pengajaran, Pendidikan, pembimbingan, pengarahan, pelatihan, penilaian, dan evaluasi anak didiknya perlu disertifikasi karena dengan sertifikasi guru yang dimiliki akan mampu mengubah pola pikir yang selanjutnya akan mampu mengubah pola perilaku yang kecendrungan ke arah positif untuk meningkatkan potensi anak didiknya. Pemberian tunjangan di luar gaji pokok yang diterima oleh guru yang tersertifikasi maka akan mendorong peningkatan motivasi, rasa tanggung jawab, disiplin, ketekunan guru dalam mengajar di kelas.

\section{Pengertian tentang Tunjangan Profesi Guru}

Tunjangan profesiguru/Insentif merupakan pemberian uang dari Pemerintah untuk para guru. Insentif dapat menjadi sarana motivasi untuk mendorong para guru bekerja dengan kemampuan yang optimal, insentif yang dimaksud merupakan pendapatan ekstra di luar gaji yang telah ditentukan. Pemberian insentif dimaksudkan agar dapat memenuhi kebutuhan para guru dan keluarga mereka. Istilah sistem insentif pada umumnya digunakan untuk menggambarkan adanya rencana-rencana pembayaran upah yang dikaitkan secara langsung atau tidak langsung dengan berbagai standar kinerja pegawai atau profitabilitas organisasi. Insentif dapat dirumuskan sebagai balas jasa yang memadai kepada pegawai yang prestasinya melebihi standar yang telah ditetapkan. Insentif merupakan suatu faktor pendorong bagi pegawai untuk bekerja lebih baik agar kinerja pegawai dapat meningkat. Metode insentif yang adil dan layak merupakan daya penggerak yang merangsang terciptanya pemeliharaan pegawai. Karena dengan pemberian insentif, pegawai merasa mendapat perhatian dan pengakuan terhadap prestasi yang dicapainya, sehingga semangat kerja dan sikap loyal pegawai akan lebih baik.

Kebijakan sertifikasi guru intinya untuk meningkatkan profesionalisme guru, dan faktor-faktor yang mempengaruhi sertifikasi guru menurut Fitra (2015) adalah: (1) Kualifikasi Pendidikan mencakup aspek tingkat pendidikan formal baik pendidikan gelar (S1 PGSD, S2, atau S3) maupun Pendidikan non gelar, (2) Kebijakan kepala sekolah terkait kemampuan kepemimpinan kepala sekolah dalam mencapai visi, misi, tujuan, dan sasaran, (3) Kesejahteraan guru berupa pemberian kompensasi atas kinerja yang diperoleh guru yang selanjutnya akan mampu memenuhi kebutuhan hidup guru (4) Lingkungan fisik tempat interaksi antara guru dan siswa, dan seorang guru harus mampu mengikuti perkembangan dan perubahan lingkungan yang terjadi (5) Pola pikir yang menjadi dasar perilaku dan tindakan sehari-hari yang selanjutnya akan membentuk kebiasaan baru yang dilakukan secara berkelanjutan, dan pola pikir tersebut dipengaruhi oleh beberapa faktor yaitu pendidikan, pengalaman, dan emosi.

Menurut Handoko (2002:176), pengertian insentif adalah perangsang yang ditawarkan kepada para karyawan untuk melaksanakan kerja sesuai atau lebih tinggi dari standar-standar yang telah ditetapkan, sedangkan menurut Panggabean (2002:93) Insentif adalah kompensasi yang me- 
ngaitkan gaji dengan produktivitas, insentif merupakan penghargaan dalam bentuk uang yang diberikan kepada mereka yang dapat bekerja melampaui standar yang telah ditentukan.

Hal tersebut sesuai dengan pendapat Hasibuan (2006:118) yang menyatakan bahwa insentif adalah semua pendapatan yang berbentuk uang, barang langsung atau tidak langsung yang diterima oleh pegawai sebagai imbalan atas jasa yang diberikan atas suatu organisasi atau perusahaan.

"Berdasarkan kajian teori dapat disimpulkan bahwa insentif adalah suatu penghargaan dalam bentuk material atau non material yang diberikan oleh pihak pimpinan organisasi perusahaan kepada karyawannya dengan tujuan agar mereka bekerja dengan motivasi yang tinggi dan berprestasi dalam mencapai tujuan-tujuan perusahaan, dengan kata lain pemberian insentif adalah pemberian uang diluar gaji sebagai pengakuan perusahaan terhadap prestasi kerja dan kontribusi karyawannya".

Zulkifli et al. (2014) melakukan riset dengan data cross sectional yang menguji tentang anteseden motivasi kerja dan sertifikasi guru terhadap kesejahteraan guru, dan dampak ikutannya pada kinerja guru. Menggunakan 244 sampel guru dari 624 populasi guru yang tersertifikasi, selanjutnya dilakukan pengujian menggunakan Structural Equation Modelling (SEM). Hasil pengujian mendukung terpenuhinya model fit dan temuan penelitiannya adalah motivasi kerja dan sertifikasi sangat berperan untuk meningkatkan kesejahteraan yang selanjutnya mampu mendukung pencapaian kinerja guru yang optimal.

\section{Insentif dan Kinerja Karyawan}

Salah satu cara manajemen untuk meningkatkan prestasi kerja, memotivasi, dan meningkatkan kepuasan kerja para karyawan adalah melalui insentif. Menurut Mathis dan Jackson (2006:24) secara sederhana insentif merupakan sesuatu yang diterima karyawan untuk balas jasa kerja mereka. Simamora (2004:114) mengatakan bahwa insentif dalam bentuk finansial adalah penting bagi karyawan, sebab dengan insentif ini mereka dapat memenuhi kebutuhannya secara langsung, terutama kebutuhan psikologisnya, namun demikian pegawai juga berharap agar insentif yang diterima sesuai dengan pengorbanan yang telah diberikan dalam bentuk non finansial dan juga sangat penting bagi pegawai terutama bagi karir mereka.

\section{Tujuan dan Manfaat Sertifikasi}

Rujukan dasar yang digunakan dalam penyelenggaraan sertifikasi guru adalah sosok utuh kompetensi profesional guru tersebut. Kanto et al. (2014) melakukan penelitian atas pengaruh kinerja guru tersertifikasi terhadap motivasi dan kepuasaan kerja di sekolah. Hasil penelitian menunjukkan bahwa terdapat pengaruh yang bervariasi sertifikasi guru terhadap motivasi dan kepuasan kerja antar guru namun tidak terlalu signifikan perbedaannya. Kepuasaan kerja guru memiliki dampak yang baik pada mutu pendidikan, di samping mampu meningkatkan produktivitas dan kinerja seorang guru juga memiliki pengaruh pada pencapaian kualitas proses pembelajaran. Penelitian yang dilakukan Apri (2012) menunjukkan bahwa kontribusi positif kepuasan kerja guru ke arah pencapaian kualitas pembelajaran diperoleh sebesar $36,8 \%$, sehingga pihak sekolah perlu mempertimbangkan dan memperhatikan kondisi yang membuat guru puas dalam bekerja di sekolah.

Peningkatan mutu guru lewat program sertifikasi ini sebagai upaya peningkatan mutu pendidikan. Rasionalnya adalah apabila kompetensi guru bagus yang diikuti dengan penghasilan yang bagus, diharapkan kinerjanya juga bagus. Apabila kinerjanya bagus maka Kegiatan Belajar Mengajar (KBM)-nya juga bagus. KBM yang bagus diharapkan dapat membuahkan pendidikan yang bermutu. Pemikiran itulah yang mendasari bahwa guru harus disertifikasi.

Adapun manfaat uji sertifikasi antara lain sebagai berikut. Pertama, melindungi profesi guru dari praktik layanan pen- 
didikan yang tidak kompeten sehingga dapat merusak citra profesi guru itu sendiri. Kedua, melindungi masyarakat dari praktik pendidikan yang tidak berkualitas dan profesional yang akan menghambat upaya peningkatan kualitas pendidikan dan penyiapan sumber daya manusia di negeri ini. Ketiga, menjadi wahana penjamin mutu bagi Lembaga Pendidikan Tenaga Keguruan (LPTK) yang bertugas menyiapkan calon guru dan juga berfungsi sebagai kontrol mutu bagi pengguna layanan pendidikan. Keempat, menjaga lembaga penyelenggara pendidikan dari keinginan internal dan eksternal yang potensial dapat menyimpang dari ketentuan yang berlaku (Muslich, 2007: 8-9).

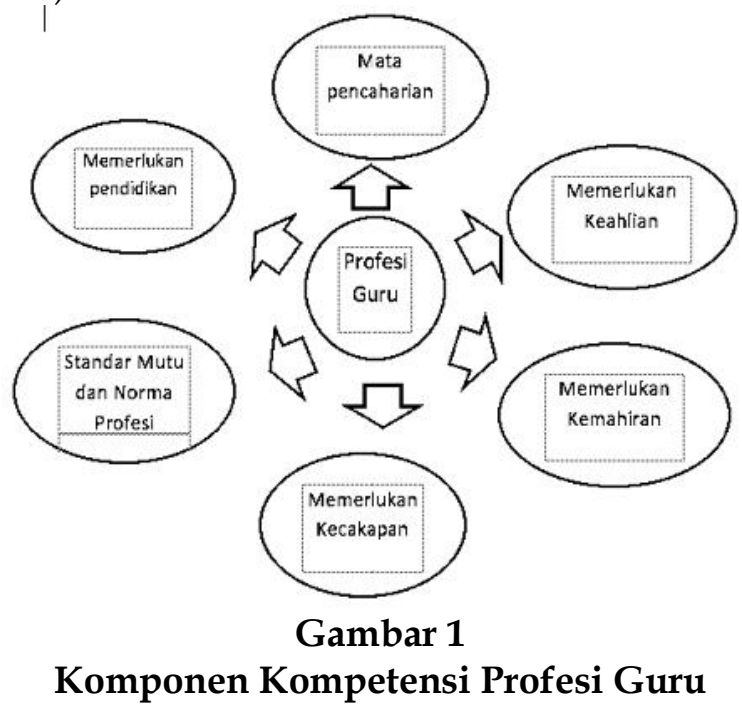

\section{Pengertian Sosialisasi}

Hortoon dan Hunt (1989:100) memberi batasan sosialisasi sebagai suatu proses yang mana seseorang menghayati (mendarah dagingkan/internalize) norma-norma kelompok tempat ia hidup sehingga timbullah "diri yang unik". Sosialisasi diberi pengertian sebagai suatu proses belajar peran, status, dan nilai yang diperlukan untuk keikutsertaan (partisipasi) dalam institusi sosial. Berbeda dengan dua definisi diatas, sosialisasi juga didefinisi sebagai suatu proses interaksi sosial yang mana memperoleh pengetahuan, sikap, nilai, dan perilaku esensial untuk keikutsertaan (partisipasi) efektif dalam masyarakat. Dari tiga definisi diatas dapat disimpulkan bahwa terdapat dua hal penting dalam suatu proses sosialisasi, yaitu satu, tentang proses, suatu transmisi pengetahuan, sikap, nilai, norma dan perilaku esensial. Kedua, tentang tujuan, yaitu sesuatu yang diperlukan agar mampu berpartisipasi efektif dalam masyarakat (Damsar,2011: 65-66).

\section{Pengertian Ekonomi}

Di dalam struktur sosial kemasyarakatan banyak terdapat ukuran-ukuran di dalam pelapisan-pelapisan yang terjadi di dalam masyarakat tersebut yang lebih dikenal dengan istilah stratifikasi sosial diantaranya adalah pelapisan yang terjadi karena kekayaan seseorang yang lebih dikenal dengan sebutan tingkat ekonomi.

Ekonomi adalah sebuah cabang ilmu sosial yang berobjek pada individu dan masyarakat, secara etimologis dapat diartikan ekonomi terdiri atas dua suku kata bahasa Yunani yaitu oikos dan nomos yang berarti tata laksana rumah tangga (Rosyidi, 2009:5). Dapat dilihat dari namanya maka pada saat pertama kali diperkenalkan ekonomi sendiri mempunyai ruang lingkup kajian dan permasalahan yang sangat terbatas yaitu hanya pada tata laksana rumah tangga dan hanya pada permasalahan mencukupi kebutuhan rumah tangga saja.

Untuk melihat defenisi ekonomi secara utuh Rosyidi (2009:7) mendefinisikan sebagai berikut: "ilmu ekonomi adalah salah satu cabang ilmu pengetahuan yang berdaya upaya untuk memberikan pengetahuan dan pengertian tentang gejala-gejala masyarakat yang timbul karena perbuatan manusia dalam usahanya untuk memenuhi kebutuhannya atau untuk mencapai kemakmuran"

Dari definisi di atas dapat dikatakan bahwa ekonomi secara umum mengkaji mengenai pemenuhan kebutuhan manusia dan kemakmuran manusia, dua hal pokok dari permasalahan ekonomi tersebut yaitu kebutuhan dan pencapaian kemakmuran merupakan salah satu dasar di dalam pelapisan sosial di dalam masyarakat bila dihubungkan dengan permasalahan mikro 
tingkat ekonomi masyarakat, dengan kata lain semakin makmur seseorang dan semakin mampu untuk memenuhi kebutuhannya dengan berbagai tingkatannya maka semakin tinggi pula tingkat ekonomi seseorang di dalam struktur sosial kemasyarakatan, lebih lanjut kita dapat melihat definisi lain seperti yang diungkap Silk (dalam Rosyidi, 2009:27).

\section{Persoalan Ekonomi}

Manusia lahir, ada dengan segala kebutuhannya. Pada awal peradaban manusia, kebutuhan ini terbatas dan bersifat sederhanam namun, dengan semakin maju nya tingkat peradaban, makin banyak dan makin bervariasi pula kebutuhan manusia. Di lain pihak, alat pemenuhan kebutuhan manusia terbatas adanya. Ketidakseimbangan antara kebutuhan masyarakat yang selalu meningkat dengan alat pemuas kebutuhan yang terbatas tersebut menyebabkan diperlukannya sebuah ilmu yang disebut ilmu ekonomi. Beberapa persoalan pokok yang diharapkan mampu dipecahkan melalui ilmu ekonomi. Persoalan-persoalan tersebut antara lain: bagaimana mengkombinasikan sumber daya yang dimiliki agar dapat menghasilkan barang-barang dan jasa untuk memenuhi kebutuhan, apa dan berapa banyak tiap barang dan jasa perlu dihasilkan, dan bagaimana pula nantinya mendistribusikan tiap barang dan jasa kepada masyarakat yang membutuhkannya.

Ilmu ekonomi yang dikembangkan oleh para pakar ekonomi telah makin maju dan canggih. Akan tetapi, ini bukan berarti semua persoalan manusia lantas berhasil diatasi. Dalam kenyataan kehidupan yang kita alami sehari-hari masih melihat saja ada masalah yang dihadapi. Secara umum, masalah yang paling besar dihadapi menyangkut persoalan-persoalan ekonomi (Deliarnov, 2005: 1-2)

\section{Rerangka Pikir}

Dari kajian teori di atas, penulis menggunakan sertifikasi guru sebagai variabel dalam mempengaruhi dampak sosial ekonomi bagi guru yang telah sertifikasi. Begitu pula sebuah teori yang dikemukakan Yamin, 2010 (dalam Istiarini dan Sukanti, 2012) faktor yang mempengaruhi kinerja guru terdiri atas faktor internal dan faktor eksternal. Salah satu faktor internal yaitu motivasi, sedangkan salah satu faktor eksternal adalah Sertifikasi Guru.

Pengujian pengaruh sertifikasi profesi guru terhadap motivasi kerja dan kinerja guru telah dilakukan oleh Murwati (2013) pada objek guru-guru di SMK Negeri seSurakarta. Hasil pengujian menunjukkan bahwa terdapat pengaruh Tunjangan Profesi Guru (TPG) pada peningkatan motivasi kerja guru yang selanjutnya akan mampu mendukung peningkatan kinerja guru. Dengan demikian sertifikasi guru merupakan stimulus yang baik dalam peningkatan mutu pembelajaran.

Sertifikasi akan berdampak pada kehidupan guru baik dalam kehidupan sosial bermasyarakat maupun dalam perekonomian.

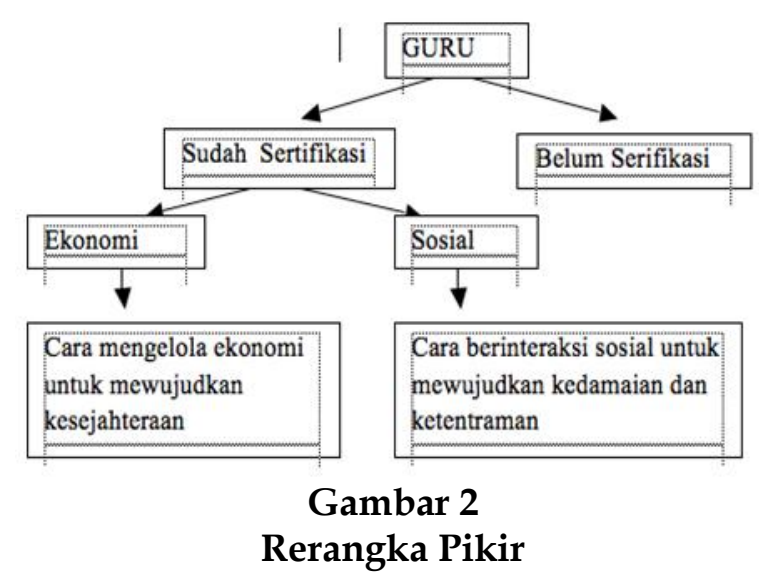

\section{METODE PENELITIAN}

\section{Jenis Penelitian}

Permasalahan yang akan dikaji oleh peneliti merupakan masalah yang bersifat sosial dan dinamis. Oleh karena itu, peneliti memilih menggunakan metode penelitian kualitatif untuk menentukan cara mencari, mengumpulkan, mengolah, dan menganalisis data hasil penelitian tersebut. Penelitian kualitatif ini dapat digunakan untuk 
memahami interaksi sosial, misalnya dengan wawancara mendalam sehingga akan ditemukan pola-pola yang jelas. Dalam penelitian ini digunakan metode kualitatif dengan desain deskriptif, yaitu penelitian yang memberi gambaran secara cermat mengenai individu atau kelompok tertentu tentang keadaan dan gejala yang terjadi (Koentjaraningrat, 1993:89).

\section{Lokasi Penelitian}

Penelitian ini mengambil lokasi di kecamatan Ngawi dan Kecamatan Geneng Kabupaten Ngawi. Alasan peneliti mengambil lokasi penelitian di kecamatan Ngawi dan kecamatan Geneng karena menurut Ngawi dalam angka tahun 2015-2016 terlihat diantaranya kasus perceraian dan kuota haji yang lumayan banyak secara umum, dan diantaranya juga ada beberapa yang berstatus sebagai guru yang sudah tersertifikasi. Dan banyak pula sekolah yang berada di kecamatan tersebut mempunyai daya tarik tersendiri untuk diteliti, karena peneliti bisa membandingkan antara sekolah yang gurunya mengajar di sekolah favorit dan sekolah yang dibilang biasa.

\section{Unit Analisis}

Unit analisis dalam penelitian adalah satuan tertentu yang diperhitungkan sebagai subjek penelitian. Dalam pengertian yang lain, unit analisis diartikan sebagai sesuatu yang berkaitan dengan fokus/komponen yang diteliti. Unit analisis ini dilakukan oleh peneliti agar validitas dan reliabilitas penelitian dapat terjaga, karena terkadang peneliti masih bingung membedakan antara objek penelitian, subjek penelitian, dan sumber data. Unit analisis suatu penelitian dapat berupa individu, kelompok, organisasi, benda, wilayah, dan waktu tertentu sesuai dengan pokus permasalahannya (Arikunto,2002).

Unit analisis berupa organisasi dapat berupa organisasi dalam skala atau level kecil atau terbatas seperti sekolah, pesantren, organisasi mahasiswa jurusan, dan lain sebagainya, maupun dalam skala besar, seperti ormas besar, perusahaan, perserikatan, dan negara. Dalam hal ini yang menjadi unit analisis dalam penelitian ini adalah guru-guru yang menerima sertifikasi dikecamatan Ngawi, Kabupaten Ngawi.

\section{Informan}

Dalam penelitian kualitatif terfokus pada informan yang dibutuhkan yang sesuai dengan apa yang diinginkan peneliti dalam hal ini berupa jawaban dan informasi. Peneliti dalam hal ini menggunakan model pengambilan purposive sampling atau sampel bertujuan yang ditentukan oleh tujuan dari penelitian tersebut.Informan adalah subjek yang memberi informasi yang dibutuhkan peneliti selama penelitian berlangsung. Didalam penelitian ini, peneliti untuk memperoleh data yang diinginkan menggunakan informan berupa aktor-aktor yang berperan penting dalam pelaksanaan pemberian sertifikasi guru-guru di Kecamatan Ngawi, Kabupaten Ngawi. Pada penelitian ini yang menjadi informan adalah: (1) Kepala Dinas Pendidikan Kabupaten Ngawi. Kepala Dinas Pendidikan dijadikan informan karena peneliti mengambil penelitian dengan tema sertifikasi, yang mana dalam hal ini kepala diknas selaku orang nomer satu di kantor Dinas Pendidikan Kabupaten Ngawi; (2) Kepala Bagian Sertifikasi Guru Kabupaten Ngawi. Karena dalam hal ini kepala bagian sertifikasi sangatlah penting bagi peneliti untuk menggali informasi karena beliau adalah seseorang yang bergerak dalam bidang sertifikasi sehingga peneliti lebih mudah untuk mencari data yang peneliti butuhkan; (3) Tokoh Masyarakat di Kabupaten Ngawi. Mengenai hal ini tokoh msyarakat akan lebih bijaksana dalam menilai masyarakat. Utamanya adalah guru sertifikasi dengan gejolak pendapatan yang lebih apakah mereka berubah kearah lebih positif dalam tindakan kesehariannya baik secara sosial maupun ekonomi; (4) Guruguru di Kecamatan Ngawi, Kabupaten Ngawi. Guru dijadikan informan karena guru di dalam penelitian ini adalah objek yang ingin diteliti dalam kaitannya dengan 
pemberian sertifikasi. Hal ini karena jumlah tersebut sesuai dengan kriteria yang diharapkan peneliti dan sesuai tujuan penelitian. Guru yang dipilih sebagai sampel memenuhi syarat yaitu sudah pernah menerima sertifikasi.

\section{Teknik Pengumpulan Data}

Teknik pengumpulan data merupakan cara yang digunakan peneliti untuk mendapat data dalam suatu penelitian. Pada penelitian ini peneliti memilih jenis penelitian kualitatif maka data yang diperoleh haruslah mendalam, jelas dan spesifik. Selanjutnya dijelaskan oleh Sugiyono (2009:225) bahwa pengumpulan data dapat diperoleh dari hasil observasi, wawancara, dokumentasi, dan gabungan/triangulasi. Pada penelitian ini peneliti menggunakan teknik pengumpulan data dengan cara observasi, dokumentasi, dan wawancara.

a) Observasi

Observasi adalah pengamatan yang dilakukan dengan sengaja dan sistematis terhadap aktivitas individu atau obyek lain yang diselidiki. Adapun jenis-jenis observasi tersebut diantaranya yaitu observasi terstruktur, observasi tak terstruktur, observasi partisipan, dan observasi nonpartisipan. Dalam penelitian ini, sesuai dengan objek penelitian maka, peneliti memilih observasi partisipan. Observasi partisipan yaitu suatu teknik pengamatan dimana peneliti ikut ambil bagian dalam kegiatan yang dilakukan oleh objek yang diselidiki. Observasi ini dilakukan dengan mengamati dan mencatat langsung terhadap objek penelitian, yaitu dengan mengamati dan meneliti pendapatan dan pendidikan terakhir orang tua terhadap prestasi siswa, sehingga peneliti dapat menentukan informan yang akan diteliti dan juga untuk mengetahui jabatan, tugas/ kegiatan, alamat, nomor telepon dari calon informan sehingga penelitia dapat dengan mudah untuk mendapat informasi yang diperlukan untuk kepentingan penelitian.

b) Wawancara

Dalam teknik pengumpulan menggunakan wawancara hampir sama dengan kuesioner. Wawancara itu sendiri dibagi menjadi 3 kelompok yaitu wawancara terstruktur, wawancara semi-terstruktur, dan wawancara mendalam (in-depth interview). Namun disini peneliti memilih melakukan wawancara mendalam, ini bertujuan untuk mengumpulkan informasi yang kompleks, yang sebagian besar berisi pendapat, sikap, dan pengalaman pribadi (Sulistyo dan Basuki, 2006:173). Untuk menghindari kehilangan informasi, maka peneliti meminta ijin kepada informan untuk menggunakan alat perekam. Sebelum dilangsungkan wawancara mendalam, peneliti menjelaskan atau memberi sekilas gambaran dan latar belakang secara ringkas dan jelas mengenai topik penelitian. Peneliti harus memperhatikan cara-cara yang benar dalam melakukan wawancara, diantaranya adalah sebagai berikut:

1) Pewawancara hendaknya menghindari kata yang memiliki arti ganda, taksa, atau pun yang bersifat ambiguitas.

2) Pewawancara menghindari pertanyaan panjang yang mengandung banyak pertanyaan khusus. Pertanyaan yang panjang hendaknya dipecah menjadi beberapa pertanyaan baru.

3) Pewawancara hendaknya mengajukan pertanyaan yang konkrit dengan acuan waktu dan tempat yang jelas.

4) Pewawancara seyogyanya mengajukan pertanyaan dalam rangka pengalaman konkrit si responden.

5) Pewawancara sebaiknya menyebutkan semua alternatif yang ada atau sama sekali tidak menyebutkan alternatif.

6) Dalam wawancara mengenai hal yang dapat membuat responden marah, malu atau canggung, gunakan kata atau kalimat yang dapat memperhalus.

c) Interview guide

Interview guide atau panduan wawancara memuat garis besar topik atau masalah yang menjadi pegangan wawancara. Bahan wawancara yang ditanyakan ditulis dalam interview guide dimana isi pertanyaan untuk pejabat-pejabat yang berwenang dalam hal sertifikasi di Kecamatan Ngawi, Kabupaten 
Ngawi, tokoh-tokoh masyarakat, dan guruguru dikecamatan Ngawi berbeda sesuai dengan informasi yang diperlukan dalam penelitian ini. Interview guide dalam penelitian ini berisi tentang pertanyaanpertanyaan yang terkait dengan pemberian sertifikasi terhadap guru-guru di kecamatan Ngawi, Kabupaten Ngawi yang secara tidak langsung berdampak pada segi sosial dan ekonomi guru-guru di kecamatan Ngawi, Kabupaten Ngawi.

d) Snowball Sampling

Teknik sampling snowball adalah suatu metode untuk mengidentifikasi, memilih, dan mengambil sampel dalam suatu jaringan atau rantai hubungan yang menerus. Peneliti menyajikan suatu jaringan melalui gambar sociogram berupa gambarlingkaran lingkaran yang dikaitkan atau dihubungkan dengan garis-garis. Setiap lingkaran mewakili satu respon dan atau kasus, dan garis-garis menunjukkan hubungan antar responden atau antar kasus. Teknik sampling snowball (bola salju) adalah metoda sampling dimana sampel diperoleh melalui proses bergulir dari satu responden ke responden yang lainnya, biasanya metode ini digunakan untuk menjelaskan pola-pola sosial atau komunikasi (sosiometrik) suatu komunitas tertentu. Snowball sampling merupakan salah satu metode dalam pengambilan sampel dari suatu populasi. Snowball sampling ini adalah termasuk dalam teknik non-probability sampling (sampel dengan probabilitas yang tidak sama). Untuk metode pengambilan sampel seperti ini khusus digunakan untuk data-data yang bersifat komunitas dari subjektif responden/sampel, atau dengan kata lain obyek sampel yang kita inginkan sangat langka dan bersifat mengelompok pada suatu himpunan. Dengan kata lain snowball sampling metode pengambilan sampel dengan secara berantai (multi level). Atau dengan kata lain, dalam penentuan sampel, pertama-tama di pilih satu atau dua orang, tetapi karena dengan dua orang ini belum merasa lengkap terhadap data yang diberikan, maka peneliti mencari orang lain yang di pandang lebih tahu dan dapat melengkapi data yang diberikan oleh dua orang sebelumnya. Begitu seterusnya, sehingga jumlah sampel semakin banyak.

e) Studi Pustaka

Yaitu Teknik pengumpulan data yang dilakukan dengan mempelajari buku-buku referensi, laporan-laporan, majalah-majalah, jurnal-jurnal dan media lainnya yang berkaitan dengan obyek penelitian.

f) Dokumentasi

Dokumen menurut Sugiyono (2009:240) merupakan catatan peristiwa yang sudah berlalu. Dokumen yang digunakan peneliti disini berupa foto, gambar, serta data-data di Dinas Pendidikan Kabupaten Ngawi. Hasil penelitian dari observasi dan wawancara akan semakin sah dan dapat dipercaya apabila didukung oleh foto-foto.

\section{Analisis Data}

Pada penelitian kualitatif proses analisis data dapat dilakukan pada saat dimulainya pengumpulan data di lapangan dan secara berkelanjutan sampai pada penulisan laporan penelitian. Data yang terkumpul selanjutnya diolah menggunakan tiga tahap:

a. Reduksi data

Proses analisis data dimulai dengan menelaah seluruh data mentah yang diperoleh dari berbagai sumber di lapangan yaitu Dinas Pendidikan Kabupaten Ngawi pada saat pengambilan data. Setelah dibaca, dipelajari, dan ditelaah, maka langkah berikutnya mengadakan reduksi data atau meringkas data yang dilakukan dengan membuat abstraksi, yaitu usaha membuat rangkuman yang inti, proses, dan pernyataan-pernyataan yang perlu dijaga sehingga tetap berada di dalamnya.

\section{b. Display data}

Setelah didapat informasi tersusun dan sebelum penarikan simpulan dan pengambilan tindakan adalah display data yang menghasilkan sajian data yang lebih spesifik. Data-data yang didapat dari hasil wawancara dari beberapa informan disatukan dan diolah kembali. Penyajian data dalam penelitian ini merupakan uraian data tentang implementasi UU RI Nomor 14 tahun 
2005 terhadap profesionalisme guru, dan Peraturan Menteri Pendidikan Nasional Indonesia Nomor 18 tahun 2007 tentang sertifikasi guru sehingga mudah dipahami. Selain itu dilakukan dengan mendeskripsikan data yang telah diperoleh dari observasi, wawancara, interview guide, dan dokumentasi.

c. Penarikan simpulan dan verifikasi.

Langkah selanjutnya adalah penarikan simpulan dan verifikasi dalam penelitian sertifikasi guru ini. Dalam analisa data ini dituntut ketajaman, kedalaman, dan keluasan wawasan agar menyentuh pada akar kebenaran sesungguhnya. Artinya selain harus mampu mengungkapkan analisis pada permukaan luar juga mampu mengungkapkan permukaan dalam, mengapa sesuatu tersebut terjadi, dalam hal ini dengan kaitannya terhadap hasil penelitian sertifikasi guru.

\section{ANALISIS DAN PEMBAHASAN}

Dampak Seritifikasi Guru terhadap Relasi Sosial Masyarakat di Kabupaten Ngawi

Pada dasarnya kehidupan di dunia ini tidak terlepas dari perubahan terhadap suatu lingkungan, baik fisik, lingkungan biologis, maupun lingkungan sosial manusia. Perbahan-perubahan sosial merupakan suatu variasi dari cara-cara hidup yang telah diterima yang disebabkan baik karena perubahan-perubahan kondisi geografis, kebudayaan materiil, komposisi penduduk, ideologi maupun adanya difusi ataupun penemuan-penemuan baru dalam masyarakat tertentu.

Menurut Soemarjan (dalam Soekanto, 1987) bahwa perubahan-perubahan sosial adalah segala perubahan pada lembagalembaga kemasyarakatan di dalam suatu masyarakat, yang mempengaruhi sistem sosialnya, termasuk di dalamnya nilai-nilai, sikap-sikap, dan pola-pola perilaku di antara kelompok-kelompok dalam masyarakat.

Stratifikasi sosial dapat diartikan sebagai perbedaan penduduk atas masyarakat ke dalam kelas-kelas secara bertingkat atau secara hierarkis. Oleh karena itu, para ahli sosiologi hukum biasanya mengemukakan suatu hipotesis bahwa semakin kompleks stratifikasi sosial dalam suatu masyarakat, semakin banyak hukum yang mengaturnya. Stratifikasi sosial yang kompleks diartikan sebagai suatu keadaan yang mempunyai tolak ukur yang banyak atas ukuran-ukuran yang dipergunakan sebagai indikator untuk mendudukkan seseorang dalam posisi sosial tertentu (Ali, 2012: 56).

Sudah menjadi suatu kenyataan yang tidak asing lagi, bahwa hukum merupakan gejala sosial sebagaimana halnya dengan ekonomi, politik, dan pendidikan. Disamping itu hukum dan gejala-gejala sosial lainnya saling mempengaruhi, namun di satu pihak, hukum dapat dipelajari tersendiri terlepas dari gejala-gejala sosial lainnya, di pihak lain ada yang lebih senang mempelajari hukum dalam kaitannya dengan gejala-gejala sosial lainnya. Mana yang lebih baik tidak akan dipersoalkan disini, sebab keduanya memang saling melengkapi, Soekanto dan Abdullah (1987).

Guru sangat berperan menggali segala potensi/kemampuan siswa dalam belajar sehingga melahirkan siswa yang berprestasi. Untuk dapat melakukan upaya ini, guru harus memiliki kemampuan (kompetensi). Program Sertifikasi Guru telah dilakukan sejak tahun 2006 sampai dengan saat ini dan telah mengklasifikasi guru dalam dua status yaitu guru tersertifikasi dan guru belum tersertifikasi. Guru tersertifikasi berhak mendapatkan tunjangan profesi, dan untuk mendapatkan tunjangan profesi harus memenuhi berbagai persyaratan.

Manusia ditakdirkan sebagai makhluk pribadi sekaligus makhluk sosial. Sebagai makhluk pribadi, manusia berusaha mencukupi semua kebutuhannya untuk kelangsungan hidupnya. Sebagai makhluk sosial dalam rangka menjalin kehidupannya, manusia selalu melakukan relasi yang melibatkan dua orang atau lebih dengan tujuan tertentu. Hubungan sosial merupakan interaksi sosial yang dinamis yang menyangkut hubungan antar individu, antar 
kelompok, ataupun antara individu dengan kelompok. Misalnya pada masyarakat perusahaan, terjalin relasi antara perusahaan dengan para masyarakat sekitar. Menurut Yudarwati (2010:146) bahwa, public relations membantu menyampaikan dan mensosialisasikan kebijakan organisasi kepada publik sehingga penyesuaian diri terjadi pada kedua belah pihak, baik organisasi maupun publik sebagai hasil kesepakatan bersama.

Menurut Indriyani (2012:65), communal relationship sebagai perwujudan rasa tanggung jawab dan kewajiban dari salah satu pihak dengan kesediaan ikut memikul tanggung jawab sosial (CSR) dan memberikan nilai tambah (added value) pada publiknya dan pada masyarakat secara umum.

Seperti yang telah kita ketahui sekarang ini Profesionalitas guru memang menjadi syarat utama mewujudkan pendidikan bermutu. Profesionalisme guru merupakan cara yang logis untuk menghadapi perubahan sosial sebagai konsekuensi globalisasi dalam berbagai bidang. Profesionalisme diyakini mampu meningkatkan kinerja yang optimal dunia pendidikan sehingga pada akhirnya dapat menciptakan cita-cita pendidikan sebagai insan yang cerdas dan berakhlak mulia, mampu menghadapi perubahan zaman, secara damai, terbuka, demokratis, dan berkompetisi yang bermuara pada meningkatnya kesejahteraan seluruh warga Indonesia. Oleh sebab itulah telah menjadi sebuah keharusan kalau setiap lembaga pendidikan dasar dan menegah di Indonesia, profesionalisme guru harus di kembangkan dan dimulai dari kegiatan belajar mengajar dan kegiatan kependidikan sehari-hari baik dikelas maupun pada organisasi guru.

Seorang guru yang lolos dari uji sertifikasi dianggap telah mampu melaksanakan kewajibannya terdiri atas kegiatan mendidik, mengajar, melatih, membimbing, dan menilai hasil belajar siswa dan harapannya mampu meningkatkan prestasi akademik siswa. Putra (2017) melakukan riset terkait hal tersebut menggunakan penelitian survey dan ex post facto (causal comparative). Riset ini menggunakan 2 variabel dan 2 kelompok terdiri atas kinerja guru dengan kelompok: (1) tersertifikasi dan (2) belum tersertifikasi. Pengujian data menunjukkan hasil terdapat pengaruh yang positif kinerja guru tersertifikasi terhadap prestasi belajar siswa sebesar 39,3\%, sedangkan pengaruh kinerja guru yang belum tersertifikasi terhadap prestasi belajar siswa sebesar $25,7 \%$.

Berdasarkan tulisan diatas dampak yang ditimbulkan oleh sertifikasi guru terhadap relasi sosial masyarakat di Kabupaten Ngawi, dapat dijelaskan sebagaimana wawancara berikut: Menurut responden 1, Laki-laki, salah satu guru SMK swasta di Ngawi, beliau memaparkan mengenai dampak sosial sertfikasi guru sebagaimana berikut: "Jika dilihat dari segi sosial guru yang mendapat sertifikasi guru, mereka biasanya memberikan sodaqoh ke teman-teman guru berupa makan bersama supaya yang belum mendapat sertfikasi juga ikut menikmati walaupun hanya sedikit. Disamping itu mereka juga memberikan upah kepada karyawan administrasi sebagai tanda terimakasih ketika dana sudah cair. Untuk sekolah swasta pemberian tunjangan sertifikasi guru memperlihatkan adanya perbedaan gaji untuk guru yang sudah empassing dan guru yang belum empassing. Gaji guru yang sudah empassing menjadi lebih besar sesuai golongan.

Jika dilihat dari kinerja Guru, dalam memenuhi kewajiban dan ketertiban mengajar masih belum bisa dikatakan maksimal di sekolah. Tidak ada perbedaan yang menyolok antara guru yang sudah mendapat sertifikasi guru dan yang belum mendapat sertifikasi guru, karena dari hasil gaji sertifikasi untuk sekolah swasta apalagi yang belum empassing perbedaan pendapatan tidak terlalu besar. Dan dari segi sosial juga tidak ada kesenjangan sosial."

Berdasarkan hasil wawancara dengan responden 1 tersebut, menyatakan bahwa sertfikasi guru tidak menimbulkan kecemburuan sosial antara guru yang belum tersertifikasi dengan yang sudah mendapat sertifikasi. Justru dengan adanya sertifikasi 
dapat mempererat sosialisasi guru-guru karena dengan adanya kenaikan tunjangan para guru dapat berbagi dengan sesama guru sehingga persaudaraan mereka lebih erat, berdasarkan hal tersebut secara tidak langsung tunjangan sertifikasi guru berdampak positif baik antar guru maupun dengan warga sekolah umumnya, khususnya untuk siswa sekolah tersebut. Dengan adanya tunjangan sertifikasi guru, pengajaran siswa-siswi di sekolah menjadi lebih baik, karena dalam satu lembaga apabila terjalin hubungan sosial yang baik maka dampaknya juga akan baik untuk semua, para guru akan menjalin kerja sama yang baik dan penyesuain diri, dengan mengurangi kecemburuan yang timbul diantara para guru tersebut. Begitu juga sebaliknya jika dampak sosial itu negatif maka akan berpengaruh buruk pada kehidupan sekolah, sehingga hubungan sosial yang positif sangat perlu terutama di sekolah karena sangat berpengaruh terhadap pendidikan peserta didik.

Berbeda halnya dengan responden ke 2, wanita, pengajar di SMPN Ngawi berpendidikan pasca sarjana dari UNS beliau juga seoarang istri yang memliki 1 suami dan 2 orang anak, di tahun ini beliau berumur sekitar 50-an tahun, sebagai individu, dan sebagai warganegara yang baik, beliau mematuhi segala ketentuan yang ditetapkan oleh Universitas tempat anaknya kuliah. Karena responden 2 sebagai pengajar yang sudah mendapat sertifikasi, beliau dikenakan biaya paling tinggi di Universitas tempat anaknya kuliah. Hal ini dirasa kurang wajar, karena banyak juga orang tua mahasiswa yang ekonominya lebih tinggi akan tetapi peringkat pembayaran masih dibawah $\mathrm{Bu}$ Siti. Secara administratif seharusnya tidak demikian terkait pemetaan pembayaran semesternya, hal ini dirasakan ada kecemburuan sosial di beberapa pihak, karena dianggap guru sertifikasi pendapatannya lebih baik daripada pegawai lain sehingga dalam pembayaran kuliah per semester justru mendapat peringkat paling mahal. Adanya intimidasi guru yang tersertifikasi sangat dirasakan oleh responden 2, yang seharusnya tidak terjadi.

Di lingkup sekolah, responden 2 juga merasakan adanya kecemburuan sosial antara guru yang belum tersertifikasi maupun pegawai non guru. responden 2 juga menuturkan adanya kecemburuan sosial tersebut dirasakan bukan hanya di lingkungan sekolah namun juga di Dinas pendidikan tempat pelayanan terhadap guru yang sertifikasi kurang baik. Hal ini juga termasuk dampak sosial sertifikasi yang mengakibatkan kecemburuan sosial antara guru yang sudah mendapat sertifikasi dengan mereka para guru yang belum sertifikasi dan pegawai non guru.

Respoden 2 juga menanggapi akan isu masyarakat yang menganggap bahwa banyak dikalangan para guru sertifikasi yang mengalami perceraian karena adanya kenaikan tingkat ekonomi namun itu semua hanya isu belaka, sertifikasi hanyalah dijadikan kambing hitam bagi pihak yang kurang bertanggung jawab. Masalah perceraian adalah masalah individu masingmasing, sertifikasi sama sekali tidak ada kaitannya dengan masalah meningkatnya perceraian yang terjadi di kabupaten Ngawi. Sebab guru yang sebelumnya mempunyai latar belakang yang baik justru karena adanya sertifikasi ini menjadi lebih baik dan tertata, bukan malah hancur keluarganya. Akan tetapi apabila ada guru yang sebelumnya sudah memiliki masalah rumah tangga dan ketika mendapatkan sertifikasi terjadi perceraian ini bukanlah sertifikasi penyebabnya.

Respoden 3, laki-laki, salah satu guru di SDN Kabupaten Ngawi ini menyatakan sebagai berikut: "Sosialisasi antar guru makin baik karena ekonomi meningkat apabila ekonomi tidak bagus orang itu cenderung emosional. Kerja juga enak, dirumah juga harmonis. Untuk dampak status sosial pandangan masyarakat kepada guru meningkat, otomatis kalau masyarakat percaya maka orangtua yang punya anak masih sekolah juga senang. Sementara dampak negatif yang timbul, adanyaguru berkelakuan kurang baik, karena dia mendapat uang yang tak 
seperti biasanya akhirnya melakukan hal yang negatif seperti berselingkuh, hal tersebut dapat terjadi karenaguru tersebut sebagai individu yang moralnya kurang baik dan secara agama kurang kuat. Apabila akhlaknya bagus dan moral bagus hal negatif tersebut tidak akan terjadi.

Persepsi masyarakat yang mengatakan bahwa angka perceraian di Ngawi meningkat karena adanya sertifikasi itu sebenarnya tidak benar. Responden 3 mengatakan, temannya yang belum tersertifikasi juga ada kasus cerai. Jadi perceraian terjadi bukan hanya guru akan tetapi di semua pegawai negri dapat ditemukan. Hal tersebut karena individu nya yang kurang baik, padaindividu yang baik hal tersebut tidak akan terjadi.

Pada umumnya perceraian terjadi karena ekonomi keluarga kurang baik, bukan karena ekonomi yang meningkat seperti adanya sertifikasi. Orang yang pandai memanage keluarga, justru menjaga keluarganya menjadi lebih baik. Perceraian dapat terjadi baik padaorang dengan ekonomi baik maupun yang kurang baik Adanya pertengkaran dalam keluarga sering terjadi atau salah satu penyebab karena ekonomi, apabila ekonomi keluarga baik justru keluarga juga baik. Apalagi guru yang awalnya sudah tertata dengan baik dengan mendapat sertfikasi justru menjadi lebih baik. Tapi sebaliknya apabila sebelumnya memang mempunyai dasar yang negatif, biasanya terjadi perselingkuhan yang berdampak pada perceraian. Karena ada satu guru yang seperti itu semua guru terkena imbasnya."

Sosial ekonomi adalah kedudukan atau posisi seseorang dalam kelompok masyarakat yang ditentukan oleh jenis aktivitas ekonomi, pendidikan serta pendapatan. Dalam pembahasannya, sosial dan ekonomi sering menjadi objek pembahasan yang berbeda. Dalam konsep sosiologimanusia sering disebut dengan makhluk sosial yang artinya manusia tidak dapat hidup wajar tanpa adanya bantuan dari orang lain, sehingga arti sosial sering diartikan sebagai hal yang berkenaan dengan masyarakat. Ekonomi barasal dari bahasa Yunani yaitu oikos yang berarti keluarga atau rumah tangga dan nomos yang berarti peraturan. Kurang meratanya pendidikan merupakan salah satu penyebab buruknya sosial ekonomi seseorang dalam masyarakat. Ada beberapa faktor yang dapat menentukan tinggi rendahnya keadaan sosial ekonomi seseorang dalam masyarakat yaitu tingkat pendidikan, jenis pekerjaan, tingkat pendapatan, keadaan rumah tangga, tempat tinggal, kepemilikan kekayaan, jabatan dalam organisasi, dan Aktivitas.

Jika dilihat sejak masa kolonialisme, pendidikan dianggap sebagai faktor penting untuk meningkatkan kesejahteraan bangsa. Masyarakat Indonesia yang biasa dikenal dengan penduduk pribumi pada masa kolonial mendapat kesempatan untuk menyekolahkan anak-anaknya, meskipun masih banyak keterbatasan karena adanya pembedaan perlakuan dalam masyarakat, adanya perbedaan jenjang pendidikan pada masa kolonial pada umumnya membuat peluang masyarakat untuk memperoleh pekerjaan lebih sedikit sehingga berdampak pada pandapatan yang mempengaruhi kesejahteraan.

Dari awal kemerdekaan sampai era reformasi kesenjangan antar provinsi masih terlihat dalam hal ini diukur dari tingkat harapan hidup, tingkat pendidikan, pembangunan serta pendapatan. Dalam hal pembangunan sosial ekonomi yang tidak merata menyebabkan tingkat kemiskinan yang masih tinggi khususnya di Indonesia. Dari beberapa hal yang telah diuraikan diatas terdapat beberapa hal yang bisa disimpulkan, bahwa dengan adanya sertifikasi guru, kini guru sudah tidak diabaikankan lagi keberadaanya. Karena dulu guru hanya pahlawan tanpa tanda jasa yang mempunyai gaji kecil, kini guru mendapat sertifikasi tentunya hal yang sangat wajar sekali, mengingat dulu guru sudah berjuang mati-matian untuk pendidikan anak bangsa tanpa mengharap apapun. Tentunya apabila dulu menanam kebaikan pasti nantinya juga akan menuai kebaikan pula, seharusnya sudah tidak ada lagi yang cemburu terhadap guru yang mendapat sertifikasi. Hal ini karena mereka tidak tahu betapa berat 
pengorbanan guru di masa lalu. Pepatah kuno dari tanah Jawa mengatakan: 'Urip iku mung sawang sinawang'. Artinya, hidup itu hanya tentang melihat dan dilihat. Karena kita melihat dan sadar bahwa kita juga dilihat, itulah sebabnya leluhur kita mengingatkan melalui pepatah kuno tersebut yang disebarkan secara tutur tinular lintas generasi dan lintas kota (bahkan provinsi). Karena penyebarannya secara tutur tinular, membuat penyampaian pepatah kuno tersebut menjadi terpotong-potong hingga yang abadi sampai sekarang hanya 'Urip iku mung sawang sinawang'. Padahal, pepatah tersebut dari penutur awalnya aslinya berbunyi: 'Urip iku mung sawang sinawang, mula aja mung nyawang sing kesawang.' Artinya, hidup itu hanya tentang melihat dan dilihat, jadi jangan hanya melihat dari apa yang terlihat. Jadi, jangan mudah menyimpulkan dari apa yang terlihat. Tidak ada sesuatu yang dihasilkan apabila orang itu tidak melakukan sesuatu, sama halnya yang dilakukan oleh para guru. Tak pantas apabila guru itu dicemburui bahkan sampai dikambing hitamkan apabila terjadi suatu kesalahan, karena dalam hadits juga dijelaskan "Al insaanu mahallul khotho' wa nisyaan" bahwa manusia itu adalah tempatnya salah dan lupa, sehingga apabila dikaitkan dengan meningkatnya angka perceraian di Ngawi itu tidak benar adanya apabila dikaitkan dengan sertifikasi guru, karena hal yang semacam itu sifatnya pribadi dan dikembalikan pada individu masing-masing.

Lain halnya dengan penuturan narasumber Responden ke 4, laki-laki, seorang guru yang belum tersertifikasi, seorang suami yang mempunyai 1 istri dan dua orang anak. Sebagai kontrol dari guru yang tersertifikasi, menyatakan bahwa sebagai pengajar, beliau melihat dan mendengar berbagai hal di sekolah, dari kegiatan belajar mengajar dan bersosialisasi dengan para guru. Di sekolah tempat beliau kerja sudah ada beberapa guru yang sudah mendapat sertifikasi, sedangkan responden ke 4 yang sudah mengajar sekitar 30 tahun masih belum mendapat sertifikasi guru, hal ini disebabkan karena responden 4 tidak mau melanjutkan studi ke jenjang S1 seperti teman-temannya. Hal tersebut dianggap tidak adil oleh respoden 4 mengingat pengabdiannya selama ini tidak bisa diukur dengan gelar saja. Banyak guru yang baru beberapa tahun mengajar sudah mendapat sertifikasi karena bergelar S1, sedangkan guru yang sudah puluhan tahun bekerja namun tidak bergelar S1 tidak mendapat sertfikasi, hal tersebut tidak adil dan akhirnya mengakibatkan kecemburuan soasial. Dalam hal meningkatnya angka perceraian di Ngawi, tidak sepenuhnya membenarkan isu tersebut akan tetapi semua itu lebih cenderung pada individu masing-masing.

Sebagaimana yang telah dipaparkan sebelumnya bahwa dampak sosial dari adanya sertifikasi guru tidak semuanya negatif, bahkan dampak yang ditimbulkan di setiap sekolah pun juga berbeda, seperti yang dituturkan oleh narasumber dari Responden ke 5 dan ke 6, laki-laki, guru SMK swasta di Ngawi ini, dijelaskan bahwa semua dampak yang ditimbulkan oleh sertifikasi ini positif tidak ada yang negatif, karena sertifikasi ini sifatnya positif dan sangat membantu untuk menunjang kebutuhan keluarga, apabila mereka mengandalkan dari gaji saja sangat tidak mencukupi.

Responden 7 wanita dan responden 8 laki-laki, guru di SD Negeri Ngawi, sudah mendapat sertifikasi, mengungkap bahwa dengan adanya sertifikasi tidak menimbulkan dampak negatif, dari segi sosial justru makin baik, kepedulian sosial makin meningkat khususnya bagi guru yang sudah sertifikasi misalnya mereka melakukan iuran untuk pembelian seragam siswa baru sehingga meringankan beban wali murid. Jadi kepedulian dan rasa sosial justru tambah baik karena uang yang diperoleh kembali ke peserta didik. Selain itu juga membagikan sebagian rejeki mereka kepada guru terutama yang masih guru tidak tetap dan membantu keperluan sekolah yang lain 
apabila ada kekurangan. Hal tersebut menunjukkan bahwa perilaku sosial di lingkungan tempat mereka mengajar tidak menimbulkan dampak negatif sebagai akibat sertifikasi guru.

Pada dasarnya manusia selalu berusaha menjalin hubungan sosial. Sebagai contoh, manusia membentuk keluarga dan melakukan aktivitas bersama anggota keluarga. Hubungan sosial yang terjalin baik dalam keluarga dapat menciptakan kehidupan harmonis. Apabila anggota keluarga tidak dapat menjaga dan menjalin hubungan baik, kehidupan keluarga tersebut akan mengalami keretakan. Untuk menciptakan kehidupan yang harmonis di lingkungan sekitar, kita hendaknya menjalin hubungan sosial yang baik. Artinya, kita berperilaku sesuai nilai dan norma sosial dalam masyarakat. Sebagai contoh, kita mengembangkan sikap toleransi dalam masyarakat agar pertentangan atau konflik dapat dihindari.

Rumah tangga merupakan unsur sosial yang paling sederhana dan berperan penting dalam menanamkan dasar-dasar sosialisasi. Keluarga merupakan institusi yang paling penting pengaruhnya terhadap proses sosialisasi individu atau seseorang. Kondisikondisi tersebut yang menyebabkan pentingnya peranan keluarga dalam proses sosialisasi. Keluarga dengan berbagai fungsi yang dijalankan adalah sebagai wahana dimana seorang individu mengalami proses sosialisasi yang pertama kali, sangat penting artinya dalam mengarahkan terbentuknya individu menjadi seorang yang berpribadi.

Sebagai bagian yang tak terpisahkan dengan masyarakat, keluarga mempunyai korelasi fungsional dengan masyarakat tertentu, oleh karena itu dalam proses pengembangan individu menjadi seorang yang berpribadi hendaknya diarahkan sesuai dengan struktur masyarakat yang ada, sehingga seorang individu menjadi seorang yang dewasa dalam arti mampu mengendalikan diri dan melakukan hubunganhubungan sosial di dalam masyarakat yang cukup majemuk.
Kepuasan kerja seorang guru menurut Apri (2012) bermanfaat bagi sekolah berkaitan dengan peningkatan produktivitas dan kinerja seorang guru, yang selanjutnya berdampak baik langsung maupun tidak langsung kepada peningkatan mutu proses pembelajaran. Hasil penelitian ini juga menyatakan bahwa kontribusi kepuasaan kerja guru terhadap peningkatan kualitas pembelajaran sebesat $36,8 \%$. Oleh karena itu penciptaan kepuasaan kerja seorang guru perlu diperhatikan karena memiliki dampak dalam peningkatan kualitas Pendidikan.

Individu yang berada dalam masyarakat tertentu berarti ia berada pada suatu konteks budaya tertentu. Pada tahap inilah arti keunikan individu itu menjadi jelas dan bermakna, artinya akan dengan mudah dirumuskan gejala-gejalanya, karena di sini akan terlibat individu sebagai perwujudan dirinya sendiri dan merupakan makhluk sosial sebagai perwujudan anggota kelompok atau anggota masyarakat.

\section{Dampak Ekonomi terhadap Guru yang mendapatkan Sertifikasi di Kabupaten Ngawi}

Pemerintah menerapkan program sertifikasi guru dalam rangka untuk meningkatkan profesionalisme guru melalui peningkatan kinerja berupa mutu Pendidikan yang semakin baik. Azwar et al. (2015) menguji pengaruh sertifikasi dan kinerja guru pada peningkatan hasil belajar siswa SMP Negeri 2 Banda Aceh. Hasil olah data penelitian yang menggunakan metode deskriptif dengan pendekatan kuantitatif pada sampel guru-guru yang tersertifikasi sebagai pendidik di SMP tersebut menunjukkan bahwa terdapat sertifikasi guru dan kinerja guru tersebut mampu meningkatkan prestasi akademik siswa.

Keragaman dalam hal menginterpretasi pendekatan-pendekatan pengembangan masyarakat semakin meluas mulai dari perbedaan orientasi nilai budaya sampai dengan tujuan dari berbagai kalangan yang menggunakan istilah tersebut. Ada yang bertujuan untuk menggeser struktur ke- 
kuatan politik, meningkatkan aktivitas ekonomi, komunitas bisnis, dan pembangunan kebudayaan. Dalam beberapa kasus, memperbaiki pelayanan dan fasilitas publik, menciptakan tanggung jawab pemerintah lokal, meningkatkan partisipasi masyarakat, memperbaiki kepemimpinan, membangun kelembagaan baru, melaksanakan pembangunan ekonomi dan fisik, dan mengembangkan perencanaan fisik dan lingkungan (Fredian, 2015:30).

Bantuan pemerintah di bidang pendidikan akan mempengaruhi dunia pendidikan melalui pencapaian kompetensi lulusan. Menurut Muzammil (2016:183), arah dan tujuan pendidikan tersebut dipengaruhi oleh corak politik berupa campur tangan pemerintah dalam pencapaian kesuksesan pendidikan masyarakat. Kegiatan ekonomi memang melingkupi semua bidang. Sebuah rumah tanggapun tidak lepas dari peran serta ekonomi. Rumah tangga yang di dalamnya terdapat satu entitas disebut keluarga, ekonomi memiliki peran sebagai pengelola arus keuangannya. Menilik kembali pengertian dasar ekonomi yaitu aktifitas pemanfaatan sumber daya alam dalam tujuannya untuk memenuhi kebutuhan manusia. Maka dikaitkan dengan lingkungan keluarga, sumber daya yang ada di dalamnya bekerja sama dalam pemenuhan kebutuhan keluarga. Sumber daya tersebut adalah SDM yang terdiri atas suami atau ayah, istri atau ibu, dan anak-anak.

Ekonomi merupakan siklus aktivitas manusia yang berkaitan dengan produksi, distribusi dan konsumsi. Tiga hal tersebut menyeluruh pada produk barang dan jasa. Sedang ilmu ekonomi adalah ilmu yang mempelajari perilaku manusia dalam meraih kemakmuran. Karena terdapat ketidak seimbangan antara kebutuhan manusia yang tidak terbatas dengan alat pemuas yang terbatas, maka disinilah fungsi ilmu ekonomi. Adalah prinsip dasarnya berupa pemanfaatan sumber daya yang terbatas atau langka untuk memperoleh keuntungan dan mencapai kemakmuran. Sumber daya manusia merupakan aset sebuah bangsa karena ia adalah pelaku utama kegiatan ekonomi, sosial, politik, agama juga budaya. Karena itulah pembangunan sebuah bangsa diawali dengan pembangunan kualitas sumber daya manusia. Kualitas berarti skill atau kemampuan diri, yang bisa diperoleh dari pendidikan. Selanjutnya, jika sumber daya manusia suatu bangsa telah berkualitas tinggi, tentu saja hal itu berpengaruh kembali terhadap kemajuan bangsa. Kemajuan dalam segala aspek perhatian pemerintah, termasuk aspek ekonomi. Perkembangan ekonomi dipengaruhi sumber daya manusia berkualitas yaitu dengan pendidikan yang baik. Sumber daya manusia yang berkualitas akan memengaruhi perkembangan dan kemajuan bangsa dalam aspek ekonomi sebagai salah satu sektor perhatian pemerintah, sehingga ekonomi memiliki hubungan timbal balik dengan pendidikan.

Dengan mengesampingkan dari dedikasi, keahlian dan keterampilan pendidik serta pengelolanya, ekonomi memiliki peran yang cukup dalam menentukan perkembangan atau kemajuan dunia pendidikan. Karena ekonomi mempunyai fungsi sebagai alat memperlancar proses pendidikan. Bukan dipandang sebagai modal yang harus kembali memberi keuntungan. Namun sejatinya keuntungan tersebut akan diterima dan dirasakan ketika nilai positif pendidikan memberi andil yang besar terhadap kesejahteraan masyarakat dan bangsa.

Maka penjelasan fungsi ekonomi pada dunia pendidikan adalah sebagai berikut:

Pertama, mencukupi keperluan pendidikan. Guna kelancaran jalannya proses pendidikan, diperlukan banyak hal seperti sarana dan prasarana, materi dan media belajarmengajar, alat peraga, juga peralatan dan perlengkapan belajar-mengajar. Disinilah peran ekonomi sebagai dana untuk memenuhi hal-hal tersebut; Kedua, membiayai operasional pendidikan. Dalam gedunggedung pendidikan terdapat instalasi listrik yang digunakan untuk alat atau media peraga, lampu, televisi, sambungan telepon, pemakaian air, dan sebagainya. Semua itu ada untuk menunjang proses belajar- 
mengajar. Dan tentu memiliki tagihan yang harus dibayar; Ketiga, membayar kegiatan penunjang pendidi kan. Misal seminarseminar pengembangan kualitas pendidik dan pengelola, pertemuan-pertemuan ilmiah ataupun non ilmiah, perayaan tertentu, biaya kepanitiaan acara, studi banding pendidikan, darmawisata dan sebagainya yang berkaitan dengan proses pendidikan; Keempat, memberikan balas jasa kepada pendidik dan pengelola lembaga. Sebagai apresiasi atas kerja keras pendidik dan pengelola lembaga pendidikan dalam kiprahnya untuk menciptakan generasi yang mumpuni, perlu adanya balas jasa yang pantas. Dan ekonomi sebagai alat pemuas balas jasa tersebut; Kelima, meningkatkan gairah dan motivasi kerja pendidik dan pengelola lembaga. Untuk memberirasa aman dan nyaman serta konsistensi etos kerja yang baik, insentif atau bahkan reward terkadang dibutuhkan. Hal ini tidak hanya berlaku dalam dunia bisnis, namun dunia pendidikan juga. Karena pada dasarnya manusia memiliki kecenderungan terjebak pada titik terendah dalam motivasi dan etos kerja. Bisa juga dikatakan sebagai titik jenuh atau kebosanan. Maka tidak menjadi sesuatu hal yang salah jika insentif atau pun reward ada untuk menghilangkan atau mencegah kecenderungan tersebut; Keenam, menciptakan kualitas lembaga pendidikan. Kebanyakan masyarakat menilai kualitas sebuah lembaga pendidikan berdasar pada tampilan fisik atau sesuatu yang terlihat. Seperti gedung lembaga yang kokoh dan besar. Ini bisa terjadi jika dibangun menggunakan dana ekonomi. Juga pendidik dan pengelola lembaga yang banyak. Ini juga bisa ada jika lembaga memiliki cukup modal untuk menggaji mereka. Namun terlepas dari hal itu, kualitas sumber daya pendidik dan pengelola lembaga lebih menjadi prioritas. Jadi, guna menciptakan kualitas lembaga pendidikan secara menyeluruh perlu adanya tunjangan ekonomi yang memadai; Ketujuh, mengembangkan bidang ilmu. Dalam perkembangan ilmu pengetahuan dan teknologi, ilmu itu sendiri memengaruhi dunia
Pendidikan, sehingga ilmu ekonomipun dipelajari seiring perkembangan dan pergerakan jaman).

Mengembangkan sumber daya manusia berperilaku ekonomi. Berperilaku ekonomi yaitu memahami dan menerapkan prinsipprinsip ekonomi seperti bersikap efisien, hidup hemat, memiliki keterampilan produktif dan efisien, mempunyai etos kerja dan sebagainya. Sumber daya manusia yang terkait dalam dunia pendidikan adalah tenaga pendidik, tenaga penunjang, dan pengelola lembaga pendidikan, serta peserta didik (siswa, mahasiswa). Dengan mempelajari ekonomi, diharapkan seluruh sumber daya manusia yang terkait mampu menerapkan prinsip-prinsip ekonomi guna kemajuan lembaga pendidik tersebut pada khususnya, dan kemajuan masyarakat serta bangsa pada umumnya.

Seperti yang telah diungakap oleh respoden 1, mengenai dampak ekonomi terhadap guru yang sudah sertifikasi: "Kalau dulu mungkin untuk menyekolahkan anak sampai jenjang S1 saja sudah dibilang berat, berkat adanya sertifikasi ini para guru bisa menyekolahkan anak ke jenjang yang lebih tinggi misal S2. Dampak positifnya pasti tetap bagus baik di lingkungan keluarga, sekolah, dan masyarakat. Otomatis untuk kerja juga tambah bergairah dan semangat. Dampak negatifnya apabila tidak bisa menggunakan uang itu dengan sebaik-baiknya biasanya untuk belanja yang berlebih akhirnya menjadi kebiasaan dan pada akhirnya malah kurang".

Berkaitan dengan manfaat yang diperoleh diperoleh informasi sebagai berikut: "Akan tetapi masih banyak dampak positif daripada dampak negatifnya. Dari segi gaya hidup bisa berpengaruh juga sekarang contohnya sebelum sertifikasi penampilan biasa saja sekarang penampilan jadi tambah baik, yang dulunya tidak punya sepeda motor sekarang punya, dan banyak juga yang beli mobil. Tapi sebelumnya yang pasti digunakan untuk menuntaskan pendidikan anaknya terlebih dahulu. Minimal S1 dan ada juga yang S2, terutama itu tadi untuk meningkatkan pendidi- kan diri sendiri yang untuk beli laptop, ikut diklat. Kalau 
itu semua sudah terpenuhi barulah memenuhi kebutuhan yang lain seperti mobil dan lain-lain. Jadi sangat berdampak positif bagi guru yang sudah tertata ekonomimya, kecuali bagi guru yang punya hutang terdahulu otomatis gajinya untuk menutup hutangnya terlebih dahulu. Dalam hal ini sangat identik dalam peningkatan kerja akan tetapi juga ada guru yang kualitas kerjanya tidak bagus, hal itu mungkin karena pembawaan. Pada umumya kalau manusia normal kerjanya semakin bagus ekonominya semakin tertata."

Adanya hubungan yang erat antara ekonomi dan pendidikan ini menurut saya sangat realistis. Teori dan praktik dari penjelasan diatas sangatlah benar dan cocok, bahwa ekonomi yang baik pastinya juga akan menghasilkan pendidikan yang baik pula. Dari segi biaya dan pemenuhan fasilitas untuk belajar sangatlah penting. Maka dampak sertifikasi dalam hal ekonomi itu sangatlah bagus, terutama untuk guru itu sendiri. Karena guru juga butuh mengkualitaskan diri dan harus bisa mengejar kreativitas dari segi tehnologi maupun non tehnologi. Tentunya semua itu tidak gratis, semua butuh biaya yang mana mereka juga harus rela merogoh dari koceknya masingmasing. Seperti membeli laptop, ikut diklat, dan mengikuti pelatihan-pelatihan, itu semua harus dipenuhi dari uang pribadi guru tersebut Secara logika apabila guru tidak mendapat tunjangan profesi, kemungkinan apa bisa memenuhi kebutuhan pendidikan yang makin meningkat.

Maka dari itu pemerintah memberi tunjangan profesi bukan semata-mata tanpa memikirkan apa kegunannya. Karena pendidikan itu mahal, kenapa pendidik dibayar murah. Sangat tidak logis bukan?. Menjadi seorang pendidik tentunya tidak semudah yang kita bayangkan, seorang pendidik harus punya kualitas pendidikan yang sangat bagus sehingga bisa melahirkan peserta didik yang bagus pula. Jadi tidak setiap guru juga bisa langsung mendapat sertifikasi, karena ada syarat-syarat tertentu yang harus dipenuhi. Penelitian tentang pengaruh kebijakan sertifikasi guru ter- hadap profesionalisme guru SD di Yogyakarta dilakukan oleh Kurniawan (2011), dan hasil penelitian menunjukkan bahwa kebijakan sertifikasi guru belum optimal untuk meningkatkan profesionalisme guru. Guru yang memperoleh sertifikasi guru cenderung mengarah pada pemikiran untuk meningkatkan kesejahteraan guru sehingga seolah-olah untuk memenuhi kebutuhan secara individu sehingga penciptaan kinerja pembelajaran belum dapat dilakukan secara optimal.

Peserta didik, mereka adalah sebagai pelaku utama juga dalam pendidikan. Apabila orang tua mereka mempunyai penghasilan yang bagus dan bisa memenuhi fasislitas pendidikan dengan baik tentunya ini juga sangat berpengaruh terhadap pendidikan. Bapak Suyadi juga mengatakan bahwa gaji sertifikasi bagi keluarganya yang paling diutamakan adalah untuk pendidikan, terutama untuk pendidikan dirinya sendiri dan pendidikan anaknya. Seperti yang kita lihat di jaman sekarang ini, dulu seorang guru maksimal hanya bisa menyekolahkan anaknya sampai jenjang S1, tapi dengan adanya sertifikasi sekarang ini banyak sekali anak guru yang sudah bisa melanjutkan studi sampai dengan jejnjang S2. Hal ini tentunya menghasilkan dampak positif juga terhadap pendidikan, tunjangan profesi yang diberikan ternyata tidak sia-sia. Hal ini menjadikan bangsa kita ini semakin maju dalam hal pendidikan. Semua orang berlomba-lomba untuk sekolah ke jenjang yang lebih tinggi, sehingga bangsa kita mempunyai warga yang berkualitas dan mempunyai dedikasi yang tinggi sehingga tidak tertinggal dengan negara-negara lain. Hal ini sangat menguntungkan bagi bangsa kita karena mempunyai generasi penerus yang bisa diandalkan.

Dalam hal lain, dampak ekonomi yang ditimbulkan oleh sertifikasi menurut responden 2 sebagai berikut: "Bagi saya pribadi sertifikasi memberikan dampak yang sangat positif bagi kelurga, ekonomi semakin membaik dan meningkat. Utamanya dari segi materi hutang semakin menipis. Saya mendapat 
sertifikasi dari tahun 2011, dan saya betul-betul menikmati. Sempat tidak punya hutang lagi dan hutang lagi untuk beli tanah, dan bisa tambah beli mobil. Akan tetapi saya malah belum ada niatan untuk haji dan umroh. Karena saya masih memikirkan kebutuhan anak jadi saya masih belum bisa untuk umroh atau haji. Dari segi ekonomi benar-benar menikmati, dan bersyukurnya lagi itu kenapa tidak dari dulu saja guru mendapat sertifikasi dengan begitu alangkah tercukupinya guru dengan adanya sertifikasi. Saya menikmatinya setelah bekerja hampir 26 tahun mengajar. Dengan begini nasib guru semakin membaik dan sejahtera daripada yang dulu, sehingga guru dapat menikmati jerih payah selam bertahun-tahun. Bagi saya pribadi tidak ada perubahan dalam gaya hidup, dia katakan berubah itu tidak cuma agak keren sedikit, kalau dulu belanja di warung sekarang ke mall. Dampak sertifikasi semua positif tidak ada yang negatif, karena betul-betul sangat membantu."

Selain berdampak terhadap pendidikan, dampak lain yang ditimbulkan oleh sertifikasi terhadap ekonomi diantaranya adalah menginvestasikan dalam bentuk tanah, mobil, naik haji, umroh. Akan tetapi tidak semua guru yang mendapat sertifikasi menggunakan uangnya dengan hal yang sama, karena mengingat kebutuhan mereka yang berbeda. Beberapa diantaranya justru ada yang tidak bisa menginvestasikan atau menabung dari hasil sertfifikasinya itu, karena sebelumnya sudah mempunyai banyak hutang sehingga dari gaji sertifikasi bisa digunakan untuk menutup hutangnya terlebih dahulu. Tentunya hal ini juga sangat membantu yang ekonomi agak sedikit goyang karena adanya beban hutang, apabila tidak ada tunjangan profesi justru mereka semakin hancur ekonominya. Hal tersebut tergantung individu masing-masing, karena keinginan tiap orang berbeda. Ada yang mungkin sudah punya mobil kemudian menggunakan uangnya untuk membeli tanah, apabila tanah sudah punya mungkin untuk daftar haji atau umroh, dalam hal ini saya kira banyak yang memlih umroh terlebih dahulu, karena waktu daftar haji sangatlah lama sehingga banyak orang yang memilih umroh. Jika kita lihat, sebenarnya dalam ekonomi sangatlah baik ketika orang yang menerima sertifikasi bisa menggunakan uangnya dengan baik dan bermanfaat, karena sudah terbukti dari beberapa responden, bahwa tunjangan sertifikasi sangat membantu sekali sehingga dia bisa merasa sangat sejahtera dari sebelum sertifikasi. mengenai hal ini ada tanggapan yang berbeda dari salah seorang narasumber, bahwa tidak semudah yang dibayangkan dalam hal membeli tanah, mobil, haji dan lain-lain. Karena mereka yang bisa itu memang dari awalnya guru tersebut sudah mapan dalam hal ekonomi, sehingga ketika dia mendapat gaji lebih atau tunjangan profesi justru sangat wajarapabila mereka mampu membelinya dengan mudah. Tanggapan yang demikian saya kira sangat wajar, karena hal ini memang masuk akal. Akan tetapi tidak semua guru membeli mobil atau tanah misalnya, dengan sekaligus lunas tapi banyak juga yang mencicil, mungkin bisa juga langsung lunas dengan cara hutang terlebih dahulu dan baru dibayar dengan cicilan tiap bulan.

Akan tetapi berbeda halnya dengan respoden yang berasal dari sekolah swasta, ada pernyataan sebagai berikut: "keluarga merasakan penghasilan yang cukup dan layak, karena dari hasil mengajar di sekolah swasta ini bisa dikatakan rendah., tercukupi terutama kebutuhan dasar, tidak lebih karena bisa dikatakan kondisi sekolah swasta belum bisa mensejahterakan guru."

Kemudian ada ungkapan lagi dari responden lain yang juga berasal dari sekolah swasta sebagai berikut: "Dirasakan jauh berbeda setelah mendapat sertifikasi karena tidak mungkin mengandalkan gaji dari sekolah untuk kehidupan sehari-hari. Semisal transportasi uang bensin ke sekolah andaikan dihitung tiap hari dari gaji tidak mencukupi belum untuk membeli buku anak-anak dan kebutuhan lain. Bisa membeli sepeda motor yang lebih layak meskipun tidak baru, untuk pergi ke sekolah meskipun cuma bekas tapi masih bagus. Gaya hidup tidak berubah karena tunjangan sertifikasi juga belum tentu keluar secara rutin." 
Disusul oleh ungkapan salah satu guru swasta juga: "Akan tetapi sementara ini saya hanya bisa memanfaatkan dana sertifikasi itu untuk kuliah saja, belum untuk hal-hal lain semisal membeli motor, mobil ataupun naik haji."

Dari beberapa pernyataan diatas, simpulannya tetap sama bahwa sertifikasi disini sangat membantu ekonomi para guru baik sekolah Negri maupun Swasta, karena sama-sama menunjang kebutuhan hidup sehari-hari, yang membedakan disini hanyalah pemakaiannya dan jumlah gaji yang didapat. Apabila guru Negri lebih banyak pendapatannya otomatis pemakaiannya pun juga lebih banyak dan menghasilkan sesuatu yang lebih besar pula, akan tetapi meskipun begitu bagi guru swasta sertifikasi yang mereka dapat juga sangat membantu dalam pemenuhan sehari-hari, belum sampai seperti pembelian mobil, tanah, haji atau semisalnya. Karena gaji yang mereka dapat dari yayasan tergolong rendah sehingga dirasa sangat kurang dalam pemenuhan kebutuhan sehari-hari. Tentunya sertifikasi yang mereka dapat sangat membantu dalam hal perekonomian keluarga.

\section{SIMPULAN DAN SARAN \\ Simpulan}

(1) Dampak seritifikasi guru terhadap perilaku sosial penerima tunjangan profesi guru di Kabupaten Ngawi, menunjukkan bahwa pemberian tunjangan atau insentif yang didapat dari sertifikasi guru di beberapa sekolah menimbulkan dampak positif maupun negatif. Untuk dampak positif hubungan antar guru menjadi lebih baik, sedangkan dampak negatif adanya kecemburuan antara guru yang mendapat insentif sertifikasi dengan guru yang tidak mendapat insentif sertifikasi; (2) Sertifikasi guru berpengaruh terhadap perilaku ekonomi penerima tunjangan profesi gurudi Kabupaten Ngawi, baik pada guru di sekolah Negeri maupun Swasta, secara ekonomi tampak dengan meningkatnya kesejahteraan hidup mereka, yang dicirikan dengan adanya beberpa guru dapat membeli sepeda motor, mobil, tanah maupun umroh dan haji.

\section{Saran}

Berdasarkan simpulan yang diperoleh diatas, dapat diberikan saran-saran sebagai berikut: (1) Menghindari kecemburuan sosial diantara guru yang sertifikasi dan yang belum sertifikasi, ataupun antara PNS guru maupun PNS non guru. Karena guru memang berhak mendapatkannya apabila kita mau memahami tugas seoarang guru dan bagaimana perjuangannya dalam hal pendidikan; (2) Tidak mengkambinghitamkan sertifikasi terhadap masalah yang dialami seorang guru, misalnya yang telah kita bahas yaitu dalam masalah perceraian. Karena memang tidak ada hubungan antara keduanya, apabila ada masalah semacam itu murni karena individu masing-masing; (3) Diharapkan pemerintah tidak mengahapus sertiifikasi guru ini, karena manfaatnya lebih banyak daripada mudhorotnya. Justru kalau bisa sertifikasi ini diaharapkan cair secara rutin, karena dengan demikian akan memperlancar proses belajar mengajar dalam dunia pendidikan di Bangsa kita ini.

\section{DAFTAR PUSTAKA}

Ali, Z. 2012. Sosiologi Hukum. Sinar grafika. Jakarta.

Alma, B. 2012. Guru Profesional. Alfabeta. Bandung.

Apri, F. 2012. Determinasi Kompetensi Profesional, Kepuasan Kerja, serta Pengalaman Kerja Guru terhadap Kualitas Pembelajaran di SMA Negeri 8 Denpasar. Jurnal Penelitian Pascasarjana Undiksa 3(2:1-19.

Arikunto, S. 2002. Metodologi Penelitian. Penerbit PT. Rineka Cipta. Jakarta.

Azwar, K., Yusrizal, dan A. R. Murniati. 2015. Pengaruh Sertifikasi dan Kinerja Guru terhadap Peningkatan Hasil Belajar Siswa Di SMP Negeri 2 Banda Aceh. Jurnal Administrasi Pendidikan 3(2): 138-147. 
Brinkerhoff, D. B. dan L. K. White. 1989. Essentials of Sociology. West Publishing Company: San Francisco.

Damsar. 2011. Pengantar Sosiologi Pendidikan. Kencana. Jakarta.

Deliarnov. 2005. Perkembangan Pemikiran Ekonomi. PT. Raja Grafindo. Jakarta.

Fitra, I. 2015. Dampak Kebijakan Sertifikasi Guru terhadap Peningkatan Profesionalisme Guru (Studi Kasus SDN 037 Kelurahan Simpang Baru Kecamatan Tampan Kota Pekanbaru Tahun 20092011). Jom Fisip 2(1) (February).

Fredian, T. N. 2015. Pengembangan Masyarakat. Departemen Sains. Jakarta.

Fuad, N. 2017. Pengaruh Sertifikasi Guru terhadap Peningkatan Kinerja Guru PAI di SMP dan MTS. Jurnal Manajemen Pendidikan 8(1): 23-32.

Handoko, H. T. 2002. Manajemen Personalia dan Sumber Daya Manusia. Penerbit BPFE. Yogyakarta.

Hasibuan, M. S. P. 2006. Manajemen Sumber Daya Manusia. Bumi Aksara. Jakarta.

Hermawan, D. 2007. Profesionalisasi dan Sertifikasi Guru dalam Meningkatkan Mutu Pendidikan.Jurnal Administrasi Pendidikan 5(1).

Horton, P. B. dan C. L. Hunt. 1999. Sosiologi. Jilid 1. Erlangga. Jakarta.

Indriyani, R. N. 2012. Pelaksanaan Organization-Public Relationship yang Dilakukan oleh Public Relations dalam Menjalin Hubungan Kerja Sama dengan Mitra Perusahaan. Skripsi. Univeristas Indonesia. Jakarta.

Istiarini, R. dan Sukanti. 2012. Pengaruh Sertifikasi Guru dan Motivasi Kerja Guru terhadap Kinerja Guru SMA Negeri 1 Sentolo Kabupaten Kulon Progo Tahun 2012. Jurnal Pendidikan Akuntansi X(1): 98-113.

Kanto, K., M. A. Ahmad, S. B. Talib, dan M. A. Tiro. 2016. The Influence of Certification Toward Work Motivation, Job Satisfaction and Performance of State High Schools Guidance and Counseling Teacher in South Sulawesi.
International Journal of Scientific $\mathcal{E}$ Technology Research 3(8). Online.

Koentjaraningrat. 1993. Metode-metode Penelitian Masyarakat. PT Gramedia Pustaka Utama. Jakarta.

Kurniawan, B. D. 2011. Implementasi Kebijakan Sertifikasi Guru dalam Rangka Meningkatkan Profesionalitas Guru di Kota Yogyakarta. Jurnal Studi Pemerintahan Universitas Muhammadiyah Yogyakarta 2(2):278-299.

Kusuma, S. T. 1987. Psiko Diagnostik. Yogyakarta: SGPLB Negeri Yogyakarta.

Mathis dan Jackson. 2006. Manajemen Sumber Daya Manusia. Salemba Empat. Jakarta.

Melati, F. K., Susilaningsih, dan Sohidin. 2013. Pengaruh Sertifikasi Guru dan Motivasi Kerja Guru terhadap Kinerja Guru SMAN 5 Surakarta. Jurnal Pendidikan (JUPE) UNS 2(1): 71-82.

Mulyasa. 2007. Implementasi Kurikulum Tingkat Satuan Pendidikan: Kemandirian Guru dan Kepala Sekolah. Bumi Aksara. Jakarta.

Murwati, H. 2013. Pengaruh Sertifikasi Profesi Guru Terhadap Motivasi Kerja dan Kinerja Guru di SMK Negeri SeSurakarta. Jurnal Pendidikan Bisnis dan Ekonomi (BISE) 1(1): 12-21.

Muslich, M. 2007. Sertifikasi Guru Menuju Profesionalisme Pendidik. Bumi Aksara. Jakarta.

Muzammil, A. 2016. Kebijakan Pemerintah dalam Bidang Pendidikan dari Orde Lama sampai Orde Baru (Suatu Tinjauan Historis). POTENSIA: Jurnal Kependidikan Islam 2(2) (Desember).

Myers, D. G. 1983. Social Psychology. McGraw-Hill Book. NewYork.

Nasution, S. 2008. Sejarah Pendidikan Indonesia. Bumi Aksara. Jakarta.

Neuman, W. L. 2003. Social Research Methods: Qualitative and Quantitative Approach. Boston: Allyn and Bacon.

Panggabean, M. S. 2002. Manajemen Sumberdaya Manusia. Ghalia Indonesia. Jakarta.

Peraturan Menteri Pendidikan Nasional Republik Indonesia Nomor 18 Tahun 2007 
tentang Sertifikasi bagi Guru dalam Jabatan.

Putra, P. 2017. Pengaruh Kinerja Guru Bersertifikasi dan Belum Bersertifikasi terhadap Prestasi Belajar Siswa di MIN se-Kabupaten Sambas. Journal of Madrasah Ibtidaiyah Education 1(1): 2017: 14-26.

Rasyid, M. A. 2014. Perbedaan Motivasi Mengajar antara Guru yang sudah Bersertifikasi dengan Guru yang belum Bersertifikasi di Sekolah Menengah Kejuruan (SMK) 7 dan 8 Negeri Kota Padang. Jurnal Administrasi Pendidikan 2 (1): 431.

Rosyidi, S. 2009. Pengantar Teori Ekonomi: Pendekatan Kepada Teori Ekonomi Mikro dan Makro. Raja Grafindo Persada. Jakarta.

Sanusi, A. 1987. Apa yang Membuat IKIP Kita IKIP. Bandung DKJP Bandung.

Sentono, P. 2009. Manajemen Sumber Daya Manusia Kebijakan Kinerja Karyawan. Edisi 1. Yogyakarta: BPFE Yogyakarta.

Simamora, H. 2004. Manajemen Sumber Daya Manusia. STIE YKPN. Yogyakarta.

Sobhron, S. 2016. Kinerja Guru Bersertifikasi dalam Meningkatkan Manajemen Mutu Pendidikan di Madrasah Ibtidaiyah
Muhammadiyah Sudun Kedungtuban. Jurnal Studi Islam 17(1): 57-67.

Soekanto, S. 1987. Sosiologi Suatu Pengantar. Raja Grafindo Persada. Jakarta.

Soekanto, S. dan M. Abdullah. 1987. Sosiologi Hukum dalam Masyarakat. Jakarta: CV. Rajawali.

Sugiyono. 2009. Metode Penelitian Bisnis (Pendekatan Kuantitatif, Kualitatif, dan $R \mathcal{E} D)$. Alfabeta. Bandung.

Sulistyo dan Basuki. 2006. Metode Penelitian. Wedatama Widya Sastra. Jakarta.

Suprastowo, P. 2013. Kajian tentang Tingkat Ketidakhadiran Guru Sekolah Dasar dan Dampaknya terhadap Siswa. Jurnal Pendidikan dan Kebudayaan 19(1): 31-49.

Undang-Undang Republik Indonesia Nomor 20 Tahun 2003 tentang Sistem Pendidikan Nasional.

Yudarwati, G. A. 2010. Community Relations: Bentuk Tanggung Jawab Sosial Organisasi. Jurnal Ilmu Komunikasi 1(2): 143-156.

Zanden, J. 1986. Sociology. The Core. New York: Alfred A. Knopf.

Zulkifli, M., A. Darmawan, dan E. Sutrisno. 2014. Motivasi Kerja, Sertifikasi, Kesejahteraan, dan Kinerja Guru. Persona. Jurnal Psikologi Indonesia (Mei 2014) 3(02): $148-155$. 